Notre Dame Law Review

Volume 90

Issue 5 Federal Courts, Practice \& Procedure

Article 4

$8-2015$

\title{
In the Beginning There Was None: Supreme Court Review of State Criminal Prosecutions
}

Kevin C. Walsh

University of Richmond School of Law

Follow this and additional works at: http://scholarship.law.nd.edu/ndlr

Part of the Constitutional Law Commons, and the Criminal Procedure Commons

\section{Recommended Citation}

Kevin C. Walsh, In the Beginning There Was None: Supreme Court Review of State Criminal Prosecutions, 90 Notre Dame L. Rev. 1867 (2015).

Available at: http://scholarship.law.nd.edu/ndlr/vol90/iss5/4 


\title{
IN THE BEGINNING THERE WAS NONE: SUPREME COURT REVIEW OF STATE CRIMINAL PROSECUTIONS
}

\author{
Kevin C. Walsh*
}

\section{INTRODUCTION}

It seems obvious that the Supreme Court must have jurisdiction to engage in direct appellate review of state criminal prosecutions that resolve questions of federal law. Federal questions are ubiquitous in state criminal prosecutions. And given the limits on federal habeas review, direct appellate review of state decisions appears essential for the Supreme Court to exercise its structural function of maintaining the supremacy and uniformity of federal law. Think of cases like Mapp v. Ohio, ${ }^{1}$ Miranda $v$. Arizona,${ }^{2}$ Crawford $v$. Washington, ${ }^{3}$ and Maryland $v$. King, ${ }^{4}$ these are just a handful of the consequential cases decided by the Supreme Court on direct appellate review of state criminal prosecutions over the years. And they are but a tiny sliver of the massively important set of cases in which the Supreme Court has engaged in direct appellate review of a state criminal prosecution. Not only is such review now routine, pervasive, and unquestioned, but it is also almost impossible for anyone to imagine that the Supreme Court ever lacked appellate jurisdiction over such cases. For almost two centuries, indeed, nobody has.

(C) Kevin C. Walsh. Individuals and nonprofit institutions may reproduce and distribute copies of this Article in any format at or below cost, for educational purposes, so long as each copy identifies the author, provides a citation to the Notre Dame Law Review, and includes this provision in the copyright notice.

* Professor of Law, University of Richmond School of Law. I thank A.J. Bellia, Marc DeGirolami, Jim Gibson, Mark Graber, Corinna Lain, Jim Lindgren, Jim Pfander, Jack Preis, Bob Pushaw, and Steven Vladeck for comments on earlier versions of this paper. I also thank participants in the Junior Faculty Federal Courts Workshop, a SEALS new faculty workshop, and a faculty workshop at the Villanova University School of Law.

1367 U.S. 643 (1961) (incorporating Fourth Amendment exclusionary rule against the states).

2384 U.S. 436 (1966) (imposing procedures for custodial interrogation under the Fifth Amendment).

3541 U.S. 36 (2004) (enforcing Sixth Amendment limits on the admission of testimonial hearsay).

4133 S. Ct. 1958 (2013) (rejecting Fourth Amendment challenge to mandatory DNA swabs incident to arrest). 
Until now. This Article challenges the unquestioned assumption of all contemporary scholars of federal jurisdiction that section 25 of the Judiciary Act of 1789 authorized Supreme Court appellate review of state criminal prosecutions. Section 25 has long been thought to be one of the most important provisions of the most important jurisdictional statute enacted by Congress. $^{5}$ The Judiciary Act of 1789 gave concrete institutional shape to a federal judiciary only incompletely defined by Article III. And section 25 supplied a key piece of the structural relationship between the previously existing state court systems and the new federal court system that Congress constructed with the Act. It provided for Supreme Court appellate review of certain state court decisions denying the federal-law-based rights of certain litigants. ${ }^{6}$

5 See, e.g., Akhil Reed Amar, The Two-Tiered Structure of the Judiciary Act of 1789, 138 U. PA. L. Rev. 1499, 1529-35 (1990) (examining the relationship between "the famous Section 25" and "the most important category of all: arising under jurisdiction"); Mark A. Graber, James Buchanan as Savior? Judicial Power, Political Fragmentation, and the Failed 1831 Repeal of Section 25, 88 Or. L. Rev. 95, 104-15 (2009) (explaining "the crucial role section 25 of the Judiciary Act of 1789 played in establishing and maintaining the Supreme Court's power to declare state-and federal-laws unconstitutional"); Paul Taylor, Congress's Power to Regulate the Federal Judiciary: What the First Congress and the First Federal Courts Can Teach Today's Congress and Courts, 37 PePp. L. Rev. 847, 861 (2010) (describing section 25 as "[o]ne of the most significant provisions of the Judiciary Act of 1789").

6 Because the text of section 25 is essential to the analysis that follows, it is set out in full here:

SEC. 25. And be it further enacted, That a final judgment or decree in any suit, in the highest court of law or equity of a State in which a decision in the suit could be had, where is drawn in question the validity of a treaty or statute of, or an authority exercised under the United States, and the decision is against their validity; or where is drawn in question the validity of a statute of, or an authority exercised under any State, on the ground of their being repugnant to the constitution, treaties or laws of the United States, and the decision is in favour of such their validity, or where is drawn in question the construction of any clause of the constitution, or of a treaty, or statute of, or commission held under the United States, and the decision is against the title, right, privilege or exemption specially set up or claimed by either party, under such clause of the said Constitution, treaty, statute or commission, may be re-examined and reversed or affirmed in the Supreme Court of the United States upon a writ of error, the citation being signed by the chief justice, or judge or chancellor of the court rendering or passing the judgment or decree complained of, or by a justice of the Supreme Court of the United States, in the same manner and under the same regulations, and the writ shall have the same effect, as if the judgment or decree complained of had been rendered or passed in a circuit court, and the proceeding upon the reversal shall also be the same, except that the Supreme Court, instead of remanding the cause for a final decision as before provided, may at their discretion, if the cause shall have been once remanded before, proceed to a final decision of the same, and award execution. But no other error shall be assigned or regarded as a ground of reversal in any such case as aforesaid, than such as appears on the face of the record, and immediately respects the before mentioned questions of validity or construction of the said constitution, treaties, statutes, commissions, or authorities in dispute. 
The received understanding of section 25, tracing back almost two hundred years and continuing into the present, is that the direct appellate review authorized by Congress in that provision encompassed both civil suits and criminal prosecutions. Professor Akhil Amar, for example, has written that "the Supreme Court was given plenary appellate review, under the famous section 25, over all state court decisions which defeated rights set up by the appellant under the Constitution, laws or treaties of the United States." 7 And Professor John Harrison has written that "Section 25 of the Judiciary Act of 1789 . . provided for federal appellate jurisdiction over state criminal prosecutions in some circumstances." 8

This consensus understanding of section 25 dates back to the Supreme Court's 1821 landmark decision in Cohens $v$. Virginia. ${ }^{9}$ Virginia prosecuted the Cohen brothers for selling lottery tickets for the congressionally created Grand National Lottery without state law authorization. ${ }^{10}$ The Cohens unsuccessfully defended on the ground that the federal statute authorizing the tickets for this lottery preempted the state's authority to regulate their sale. ${ }^{11}$ Chief Justice Marshall's issuance of a writ of error pursuant to section 25 provoked a massive jurisdictional battle-one of the most significant controversies to face the Court under Chief Justice Marshall. ${ }^{12}$ But that battle was almost exclusively about the Court's jurisdiction under Article III. ${ }^{13}$

Judiciary Act of 1789, ch. 20, § 25, 1 Stat. 73, 85-87 (1789).

7 Amar, supra note 5, at 1519 (quoting Akhil Reed Amar, A Neo-Federalist View of Article III: Separating the Two Tiers of Federal Jurisdiction, 65 B.U. L. Rev. 205, 260-62 (1985)) (emphasis added).

8 John Harrison, The Power of Congress to Limit the Jurisdiction of Federal Courts and the Text of Article III, 64 U. CHI. L. Rev. 203, 234 (1997).

919 U.S. (6 Wheat.) 264 (1821).

10 This lottery was designed to raise money for capital improvements in the District of Columbia. Lotteries were an important means of raising government revenue at this time, and states like Virginia had begun to regulate them because they diverted potential government revenue from in state to out of state and because national lottery businesses like the Cohens's functioned in many ways like banks given the amount of money flowing through them and the liquidity of the market for various lotteries' tickets. See W. Ray Luce, Cohens v. Virginia (1821): The Supreme Court and State Rights 1 (1990) (noting that " $[\mathrm{m}] \mathrm{uch}$ of the nation's capital accumulation came from lotteries, and most lottery offices performed a variety of financial and banking services"); $i d$. at 23 (explaining that Virginia's 1819 ban on the sale of lottery tickets not authorized by Virginia was justified "as necessary to stop a cash outflow that paid for other states' internal improvements when similar Virginia projects faced financial difficulties").

11 This was a potent argument coming just one year after the Supreme Court held in McCulloch v. Maryland that states could not tax the federally incorporated (but privately owned and operated) Second Bank of the United States. See McCulloch v. Maryland, 17 U.S. (4 Wheat.) 316, 419-24 (1819).

12 See LuCE, supra note 10, at xiv (noting that "[c] riticism of the Court and the Cohens decision lasted more than a year and proved to be the most extensive opposition the Court received during John Marshall's tenure as Chief Justice").

13 Virginia's lawyers did argue that the Supreme Court lacked statutory jurisdiction under section 25. But this statutory argument did not focus on criminal prosecutions as a category. The argument, instead, was a repackaged version of Virginia's argument on the 
The Court held in Cohens, as a constitutional matter, that the Supreme Court had appellate jurisdiction to engage in direct review of state criminal prosecutions that fit within Article III's extension of the federal judicial power to cases arising under federal law. The claim that there was no statutory jurisdiction in Cohens because section 25 did not encompass direct appellate review of state criminal prosecutions by the Supreme Court of the United States was neither raised nor decided in the case. Although the Court had not previously used its statutory authority under section 25 to review a state criminal prosecution in the thirty-plus years between the Judiciary Act of 1789 and the writ of error in Cohens, the Supreme Court's practical extension of section 25 review in that case was almost entirely ignored as a matter of statutory interpretation.

With the exception of a lone constitutional lawyer from Ohio who criticized the decision when it came down, no lawyer, judge, or scholar seriously argued in the wake of Cohens $v$. Virginia that section 25 of the Judiciary Act did not authorize Supreme Court review of state court criminal prosecutions. The single-and singular-exception was the astute and once eminent (but now obscure) Charles Hammond, who died in $1840 .{ }^{14}$ Writing in the immediate aftermath of Cohens, Hammond advanced a civil-only interpretation of section 25 in the tenth essay of a remarkable series of eleven pseudonymous newspaper essays written under the pen name of "Hampden." 15

merits. Virginia's lawyers argued that the allegedly preempting federal lottery statute was not a federal law within the meaning of section 25 because Congress enacted it as local legislation for the District of Columbia. The lawyers advanced this claim about the nature of the allegedly preempting law in their arguments about jurisdiction because they had been forbidden by the Virginia legislature from arguing the merits of the case if the Court were to determine that it possessed jurisdiction. The jurisdictional packaging enabled them to make their arguments about the limited reach of the national lottery law while respecting the limits imposed by Virginia on their Supreme Court representation of the state.

14 Charles Hammond has been so neglected that he did not even have his own Wikipedia before this Article was written. I remedied that while writing this Article. See Charles Hammond (lawyer and journalist), WIKIPEDIA, http://en.wikipedia.org/w/index.php? title=CharlesHammond_(lawyer_and_journalist) \&oldid=616957675 (last visited Mar. 10, 2015).

15 Charles Hammond, Review of the Opinion of the Supreme Court of the United States in the Case of Cohens v. Virginia (1821). Hammond's choice of "Hampden" was unfortunate. This was the same pseudonym previously adopted by Virginia judge (and fierce Marshall Court critic) Spencer Roane in the set of critical newspaper commentaries that led Chief Justice John Marshall himself to take to the newspapers and respond pseudonymously. See John Marshall's Defense of McCulloch v. Maryland 15-16 (Gerald Gunther ed., 1969). Charles Warren-the former Harvard Law professor and early twentieth-century author of what one scholar recently described as a "magisterial" history of section 25's application and " $[\mathrm{t}]$ he most important study on the politics of federal jurisdiction before the Civil War" - was confused into attributing Hammond's "Hampden" essays to Roane. See 2 Charles Warren, The Supreme Court in United States History: 1821-1825, at 15 (1922) (attributing Hammond's "Hampden" essays to Roane); Graber, supra note 5 , at 100 . 
Although Hammond stood alone in staking out his civil-only interpretation of section 25 after Cohens, his arguments were not idiosyncratic when considered against the backdrop of what came before. When Congress enacted the Judiciary Act of 1789, there was very little reason for Congress to have contemplated the application of federal law in state criminal prosecutions. There was no Fourteenth Amendment, and incorporation of constitutional rights of criminal procedure was far beyond the horizon. Apart from the prohibition on ex post facto laws, Congress would not have worried about state court circumvention of the Constitution in criminal prosecutions. Just five years prior to Cohens, Justice William Johnson had argued in his separate opinion in Martin v. Hunter's Lessee that the Supreme Court had been given no appellate jurisdiction to review state court criminal prosecutions. ${ }^{16}$ But this civil-only interpretation of section 25 simply disappeared after 1821 . Justice Johnson abandoned it without explanation in Cohens, everyone ignored Hammond, and Supreme Court practice shifted quickly and irreversibly to include direct appellate review of state court criminal prosecutions under the jurisdiction granted in section 25. Fights over the Supreme Court's appellate jurisdiction to review state court decisions flared up, but they were framed as fights over whether to repeal section 25 or whether section 25 was constitutional, rather than as fights over section 25's correct legal meaning. ${ }^{17}$

Although Hammond's arguments were seemingly stillborn when delivered in the summer of 1821, their continuing vitality should be apparent to lawyers today. This Article resurrects Hammond's arguments and contends that he was right: the best interpretation of section 25 is that it did not encompass Supreme Court appellate review of state criminal prosecutions.

Others may reasonably disagree with this Article's ultimate interpretive conclusion about section 25's limited reach even while acknowledging the strength of the various supporting arguments. Accordingly, this Article's basic claim comes in both a strong version and a weak version. The strong version has already been stated: Section 25's authorization of Supreme Court appellate review of state court decisions was limited to civil suits and did not extend to criminal prosecutions. If this strong version is correct, the Supreme Court should have dismissed Cohens $v$. Virginia for lack of statutory jurisdiction. ${ }^{18}$ The weak version is that the arguments for a civil-only inter-

16 See Martin v. Hunter's Lessee, 14 U.S. (1 Wheat.) 304, 377 (1816) (opinion of Johnson, J.) ("At present the uncontrollable exercise of criminal jurisdiction is most securely confided to the state tribunals. The courts of the United States are vested with no power to scrutinize into the proceedings of the state courts in criminal cases ....").

17 See Charles Warren, Legislative and Judicial Attacks on the Supreme Court of the United States-A History of the Twenty-Fifth Section of the Judiciary Act, 47 Am. L. Rev. 1, 4 (1913) (identifying ten federal jurisdiction-stripping proposals between 1821 and 1882).

18 With the exception of cases within the Supreme Court's original jurisdictionwhich is self-executing, see James E. Pfander, Rethinking the Supreme Court's Original Jurisdiction in State-Party Cases, 82 CALIF. L. REv. 555, 558 n.12 (1994)-the authority of a federal court to exercise jurisdiction over any case depends on congressional action. The way that this works varies between the Supreme Court, which is created by the Constitution, and the inferior courts, which depend on Congress for their existence. The Supreme Court's 
pretation of section 25 were sufficiently strong at the time of Cohens that the Court permissibly could have dismissed for lack of statutory jurisdiction. Even if not demonstrably compelled by the jurisdictional statute, this disposition would not have required any stretching of it.

This Article proceeds in three parts. Part I sets out the basic arguments from text and context that support a civil-only interpretation of section 25 . Part II addresses the strongest objections. And Part III explores the broader significance of the surprising rediscovery of civil-only section 25 .

There is no need to prolong this introduction with previews of Parts I and II, which one can find at the opening of those Parts. But it is useful to say more right here about Part III-why these arguments matter. After all, section 25 no longer governs. The current statute governing Supreme Court review of state decisions plainly encompasses both civil and criminal cases. ${ }^{19}$ And Congress will never take away that authority. Indeed, there are arguments tending to establish that Congress would not even constitutionally be able to do so if it wanted to.

Interestingly enough, those arguments about the limits of congressional control over federal court jurisdiction provide the first of several reasons why a civil-only understanding of Section 25 still matters. A standard form of argument about congressional control over federal jurisdiction is based on correspondence or lack of correspondence between the Judiciary Act of 1789 and Article III. The extent of congressional control over federal jurisdiction is precisely what Professor Amar and Professor Harrison were arguing about in the articles quoted above on the reach of section 25. Professor Amar and others have argued that Article III mandates federal jurisdiction in original or appellate form in certain types of cases, ${ }^{20}$ while Professor Harrison and others have argued the Article III is not mandatory. ${ }^{21}$ Insofar as the first Congress is taken to be an authority on constitutional meaning-itself a contested issue-those who argue for a mandatory theory of Article III need to

appellate jurisdiction is to be understood pursuant to " $[\mathrm{t}]$ he principle that the affirmation of appellate jurisdiction implies the negation of all such jurisdiction not affirmed." Ex parte McCardle, 74 U.S. (7 Wall.) 506, 513 (1868). Accordingly, the Supreme Court may not hear an appeal unless the case fits within a statutory grant of jurisdiction that encompasses it.

19 See 28 U.S.C. $\$ 1257$ (a) (2012) ("Final judgments or decrees rendered by the highest court of a State in which a decision could be had, may be reviewed by the Supreme Court by writ of certiorari where the validity of a treaty or statute of the United States is drawn in question or where the validity of a statute of any State is drawn in question on the ground of its being repugnant to the Constitution, treaties, or laws of the United States, or where any title, right, privilege, or immunity is specially set up or claimed under the Constitution or the treaties or statutes of, or any commission held or authority exercised under, the United States.”).

20 See, e.g., Amar, supra note 5 at 1565-67; Robert J. Pushaw, Jr., Congressional Power Over Federal Court Jurisdiction: A Defense of the Neo-Federalist Interpretation of Article III, 1997 BYU L. REv. 847, 870.

21 See, e.g., Harrison, supra note 8, at 234; Daniel J. Meltzer, The History and Structure of Article III, 138 U. PA. L. Rev. 1569, 1575 (1990). 
contend with the gap between what they say Congress was constitutionally required to authorize and what the first Congress actually did authorize. If the strong version of this Article's claim is correct, then this gap is larger and more significant than anyone until now has thought. ${ }^{22}$

Chief Justice Marshall's perspective on the Judiciary Act of 1789 in Cohens $v$. Virginia supplies an additional reason for believing it worthwhile to get a better fix on the meaning of this foundational statute. The non-controversial existence of section 25 appellate review generally, he claimed in Cohens, is reason to think that Supreme Court appellate review of state court decisions on questions of federal law is constitutionally authorized. ${ }^{23}$ Marshall did not think the first Congress infallible, as evidenced by his opinion for the Court in Marbury $v$. Madison holding section 13 of the Judiciary Act of 1789 partially unconstitutional. But he did understand the first Judiciary Act as "[a] contemporaneous exposition of the constitution" of no less authority than the Federalist Papers-which, he also said in Cohens, have "always been considered as of great authority." 24

The path trod in this article is Chestertonian; it proceeds from the view that " $[\mathrm{t}]$ he whole object of travel is not to set foot on foreign lands; it is at last

22 The suggestion that civil-only section 25 shows a larger gap between constitutionally authorized and statutorily provided jurisdiction assumes that the Supreme Court correctly decided in Cohens that appellate review of certain state criminal prosecutions deciding federal questions was within the Court's jurisdiction under Article III. For purposes of situating this Article's excavation of civil-only section 25 in current scholarly debates, that is a safe assumption. At this point, it is now taken as well established that the Supreme Court's decision in Cohens is consistent with the original legal meaning of Article III. See Anthony J. Bellia, Jr., The Origins of Article III "Arising Under" Jurisdiction, 57 Duke L.J. 263, 326-31 (2007) (situating Cohens within a broader explanation of "arising under" jurisdiction). But maybe that is wrong. Maybe Congress did not provide statutory jurisdiction for Supreme Court appellate review of these state court criminal prosecutions because it could not. I am not prepared to reach that conclusion on the basis of present research and am inclined to think such a conclusion incorrect. The best understanding still appears to be that a case arises under federal law " $[w]$ hen the Constitution, laws, or treaties of the United States, by operation of their own force, create or are otherwise determinative of a right asserted in a case." Id. at 331. But the rediscovery of civil-only section 25 and of Charles Hammond as a guide in the exploration of federal jurisdiction demonstrates the need for renewed investigation of this topic. My present working understanding with respect to Article III is that Cohens properly liquidated the meaning of Article III, but that the alternative conclusion of no constitutional jurisdiction would also have been a permissible (but inferior) means of liquidating the constitutional text.

23 See Cohens v. Virginia, 19 U.S. (6 Wheat.) 264, 420 (1821) ("A contemporaneous exposition of the constitution, certainly of not less authority than that which has just been cited, is the judiciary act itself. We know that in the Congress which passed that act were many eminent members of the Convention which formed the constitution. Not a single individual, so far as is known, supposed that part of the act which gives the Supreme Court appellate jurisdiction over the judgments of the State Courts in the cases therein specified, to be unauthorized by the constitution.").

$24 I d$. at 418, 420; see also id. at 418 ("It is a complete commentary on our constitution; and is appealed to by all parties in the questions to which that instrument has given birth. Its intrinsic merit entitles it to this high rank."). 
to set foot on one's own country as a foreign land."25 Traveling the land of federal jurisdiction through the dense underbrush of the text of section 25 brings one back to the familiar words of Article III, but now bearing a new appreciation for the difficult problems they pose. Careful parsing of the precise and detailed language of the Judiciary Act of 1789 provides insight into the jurisdictional thinking not only of the first Congress but also more broadly of the legal world in which Article III was ratified. Appreciating how Congress very well may have actually structured the federal judiciary differently than is now commonly thought that Congress did enables insight into how Article III may have been liquidated differently than it ultimately was. Indeed, if the Judiciary Act of 1789 did not authorize Supreme Court appellate review of state criminal prosecutions, and if this had been recognized in Cohens, the Court would not have had occasion to resolve various tensions in Article III as it did. Article III doctrine may have developed dramatically differently than it did due to Cohens. And this recognition, in turn, helps those who wish to understand what Article III was before it became what it now is. To paraphrase Chesterton, "the only way to go to [Article III] is to go away from it." 26

Reflecting on the weak version of this Article's claim also illuminates the nature of the Marshall Court's judicial nationalism. Once we see that no statutory jurisdiction over criminal prosecutions was an easily available option for the Supreme Court in Cohens v. Virginia, we can ask: Why was this a road not taken? The obvious answer is that such a holding would have been entirely unsatisfactory for a Court that was to play the strong role as the voice of the Constitution and of the American people that Chief Justice Marshall and his brethren envisioned in Cohens. If the Court had held that the Constitution authorized jurisdiction but Congress had not provided it, there was no way that Congress would have provided that jurisdiction any time soon. Yet the Court needed jurisdiction that it could use in the present-even when doing so would result in rulings that were likely to be disobeyed or ignored.

In the end, Cohens $v$. Virginia is a masterpiece of judicial craftsmanship that has so powerfully shaped subsequent thinking about federal jurisdiction that lawyers, judges, and scholars today cannot help but take its correctness for granted. The opinion so persuasively elaborates Chief Justice Marshall's constitutional vision for direct appellate review of state courts by the Supreme Court that the more limited congressional vision that may actually have been embedded in section 25 has been buried and forgotten. If nothing else, then, disinterring the arguments for civil-only section 25 provides a better understanding of the materials that the Supreme Court's greatest judicial craftsman had to work with in Cohens $v$. Virginia.

And yet there is something else. The strongest reason for believing that the correct interpretation of section 25 still matters now is that interpreting this foundational provision correctly matters, period. Judicial and scholarly

25 G.K. Chesterton, Tremendous Trifles 204 (3d ed. 1909).

$26 I d$. 
understandings of the federal judicial power rely on claims about the original legal meaning of Article III and the Judiciary Act of 1789. And this Article's inquiry into the original legal meaning of section 25 takes the conventional approach of inquiring how a reasonable lawyer versed in the Constitution, laws, and background legal principles of the time would have understood this provision. ${ }^{27}$ The departure from existing scholarship is not in method but in result. Until this Article, scholars of federal jurisdiction have uniformly understood section 25 as encompassing both civil and criminal cases. But if the strong version of this Article's basic claim is right, that until now uniform understanding is wrong. New editions of old books will need to be revised to account for this interpretation, as will all accounts of the Judiciary Act of 1789 going forward. And that is so even if many scholars ultimately accept only the weak version of this Article's basic claim. The arguments for civilonly section 25 simply cannot be ignored by anyone seeking to understand the establishment and development of federal jurisdiction.

\section{Argument}

This part sets forth the affirmative case for civil-only section 25 as a matter of statutory interpretation. The argument is primarily textual. But while the analysis that follows proceeds through the text piece by piece, it is important to keep in mind how these pieces fit together, as well as how section 25 fits with the rest of the Judiciary Act of 1789 and within the legal universe of the late eighteenth and earlier nineteenth centuries. Before turning to elaboration of each part of the argument, then, it is helpful to begin with an outline of its main pieces.

The first feature of section 25 discussed below is that it provided for a writ of error in "any suit," not "any case" or "any suit or prosecution." As used elsewhere in the Act and as used by the same Congress, "suit" referred to civil cases only. The Constitution, by contrast, used the broader term "case" to encompass both civil suits and criminal prosecutions. And when Congress wanted to refer to criminal prosecutions, it used "prosecution" or "proceedings" in addition to (or as an alternative to) "suit."

Second, the writ of error was available only once a suit has reached final judgment "in the highest court of law or equity of a State in which a decision in the suit could be had. . .."28 At its broadest, this language authorizes the

27 See, e.g., Anthony J. Bellia, Jr. \& Bradford R. Clark, The Alien Tort Statute and the Law of Nations, 78 U. CHI. L. Rev. 445, 453 (2011) (investigating "the original meaning of the [Alien Tort Statute] in its historical context"); cf. John F. Manning, Separation of Powers as Ordinary Interpretation, 124 HaRv. L. Rev. 1939, 1975 (2011) (proceeding under the "conventional assumption that constitutional interpretation entails recovering or reconstructing the historically situated meaning of the constitutional text"); John O. McGinnis \& Michael B. Rappaport, Original Methods Originalism: A New Theory of Interpretation and the Case Against Construction, 103 Nw. U. L. Rev. 751, 751 (2009) (arguing that "the Constitution should be interpreted using the interpretive methods that the constitutional enactors would have deemed applicable to it").

28 Judiciary Act of 1789, ch. 20, § 25, 1 Stat. 73, 85-87 (1789). 
Supreme Court to review even those cases-like Cohens itself-in which the state system provided no appeal at all. This language invites consideration of the jurisdictional landscape for appeals in criminal prosecutions, which looked quite different in the late eighteenth and early nineteenth centuries than it looks today. There were no intrastate appeals in many criminal cases; there was no Supreme Court appellate review in any federal criminal cases; there was no Supreme Court appellate review in criminal cases coming out of the D.C. courts; and there was no Supreme Court appellate review in criminal cases coming out of territorial courts. Against this backdrop, it is conceivable that section 25 nevertheless authorized Supreme Court appellate review of state criminal prosecutions. But it is unlikely that section 25 would have passed without substantial critical commentary on this point-as it did-if Congress had provided such appellate jurisdiction.

Third, section 25 provided that the writ of error shall be issued in state court cases "in the same manner and under the same regulations" as in cases from the federal circuit courts. ${ }^{29}$ Yet writs of error could not be issued to circuit courts in criminal prosecutions, and were limited in civil suits by an amount-in-controversy requirement. As late as 1816, a Justice of the Supreme Court described state criminal cases as beyond the reach of the Supreme Court, and other evidence from this time also reveals a belief that section 25's "under the same regulations" language incorporated the amount-in-controversy requirement applicable in cases appealed from the circuit courts. Even though the Supreme Court held in 1823 that section 25 did not incorporate this requirement, the Supreme Court (seemingly unaware of this earlier decision) later interpreted identical "in the same manner and under the same regulations" language to foreclose Supreme Court appellate review of criminal cases from territorial courts.

Fourth, section 25 authorized the Supreme Court itself to award execution of judgment under certain conditions. But the Court was not granted authority to order a new trial or authorized to issue compulsory process against state courts, which would have been essential to ensuring execution of judgments of reversal in criminal cases.

These textual features, singly and together, provide strong support for a civil-only understanding of section 25. That understanding comports with important and widespread differences in the availability of appellate review in civil and criminal cases in the late eighteenth and early nineteenth centuries. And as we shall see, a civil-only understanding of section 25 is consistent with both the legislative history of the Act and its pre-Cohens reception.

\section{A. "any suit"}

Section 25 authorized Supreme Court appellate review via writ of error in "any suit, in the highest court of law or equity," if the state court hearing the suit decided a question of federal law against the party relying on federal

$29 I d$. 
law. ${ }^{30}$ In light of section 25's limited reach to a subset of state court resolutions of federal law questions, Congress probably understood this provision to be authorized by Article III's extension of federal judicial power to "all Cases, in Law and Equity, arising under this Constitution, the Laws of the United States, and Treaties made, or which shall be made, under their Authority."31 The first observation to make about section 25's potential reach to criminal cases, then, is that the statutory language of "any suit, in the highest court of law or equity" is different from, and seemingly narrower than, the constitutional language of "all cases, in law and equity."32

The case for understanding "suits" as distinct from "cases," and thus not extending to include criminal prosecutions, takes its bearings from the only contemporaneous critical commentary about Cohens $v$. Virginia research has revealed that addressed section 25's extension to criminal prosecutions. This is "Essay X" of Charles Hammond's "Hampden" essays on Cohens. ${ }^{33}$ One of Hammond's lead arguments for a civil-only interpretation of section 25 was that "suit" in section 25 does not include criminal cases. ${ }^{34}$ Although Hammond did not break it down in precisely this fashion, this argument about the meaning of "any suit" comes in an ordinary meaning and an intratextual variety. The ordinary meaning argument is that " $[\mathrm{t}]$ he term suit is not ordinarily used to describe a public prosecution." 35 The intratextual argument is that, in every other part of the Judiciary Act of 1789, "the term suit is used in reference to a civil and not a criminal proceeding." 36

Before turning to the intratextual evidence and then to other evidence of how Congress used "suit" in section 25, it is important to acknowledge that there is one inclusive but uncommon meaning of "suit" that encompasses both civil and criminal matters. Both this broad meaning and the more ordinary, civil-only meaning can be seen in Blackstone's Commentaries on the Laws of England. Blackstone divided his two books on "wrongs" between "private wrongs" (Book III) and "public wrongs" (Book IV). ${ }^{37}$ Book III is largely devoted to the "redress of private wrongs, by suit or action in the courts." 38 Book IV, by contrast, studies the criminal law, or what Blackstone called the "pleas of the crown" because the king "is supposed by the law to be the person injured by every infraction of the public rights belonging to [the] community, and is, therefore, in all cases, the proper prosecutor for every public

$30 I d$. This formulation oversimplifies in describing the characteristics of covered state court decisions vis-à-vis the Constitution, federal law, and treaties, but the simplification is not material to the portion of statutory text relevant for this argument. For the full text, see supra note 6.

31 U.S. Const. art. III, § 2.

$32 I d$.

33 Charles Hammond, No. $X$, in Review of the Opinion, supra note 15, at 51-55 [hereinafter Hampden $X]$.

34 See id. at 53, 54.

35 Id. at 52.

$36 \quad I d$. at 53.

37 See 3 William Blackstone, Commentaries *2.

38 Id. at $* 3$. 
offense."39 Blackstone's discussion of the various processes for enforcing the criminal law is titled "Of the Several Modes of Prosecution." 40 There is some overlap between the idea of "suit" and "prosecution," as Blackstone describes processes like indictment and presentment as "methods of prosecution at the suit of the king," 41 and he also uses the phrase "criminal suit" in describing a prosecution initiated by information. Moreover, Blackstone notes that one method of enforcing certain penal statutes was a qui tam "suit," in which an informer would bring "suit" to recover a penalty or portion of a penalty due for the commission of a public wrong. ${ }^{42}$ But despite the possibility of a broad use of "suit" to include the idea of a "criminal suit," the much more common term for actions to enforce criminal laws in Blackstone's Commentaries is "prosecution." And the claim of this Section is that, although it is conceivable that Congress used "suit" inclusively to extend to criminal prosecutions as well as civil cases, the better conclusion is that Congress used the word to encompass civil cases only.

We begin, then, with the intratextual evidence, which provides strong but not unequivocal support for a civil-only meaning of "suit" in section 25. The strongest intratextual evidence comes from section 35 of the Act, which distinguishes "suits" from "prosecutions" in describing the office of United States Attorney. ${ }^{43}$ As used in this part of section 35, "suits" corresponds to "civil actions" while "prosecutions" refers to "crimes and offences."44

The next strongest intratextual evidence comes from sections 12 and 31 . Each of these sections appears to use "suit" to encompass civil cases alone. Section 12 provides for removal of "a suit . . commenced in any state court

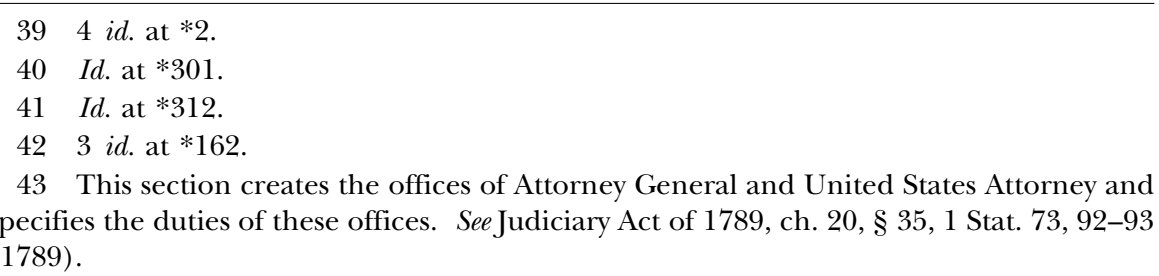

44 See id. (" $[\mathrm{T}]$ here shall be appointed in each district a meet person learned in the law to act as attorney for the United States in such district, whose duty it shall be to prosecute in such district all delinquents for crimes and offences, cognizable under the authority of the United States, and all civil actions in which the United States shall be concerned, except before the supreme court in the district in which that court shall be holden. And he shall receive as a compensation for his services such fees as shall be taxed therefor in the respective courts before which the suits or prosecutions shall be." (emphases added)). Another part of section 35 that arguably cuts the other way is the description of the Attorney General's duties as including the conduct of "all suits in the Supreme Court in which the United States shall be concerned." If this authorization included the conduct of criminal cases, then Congress used "suits" broadly to encompass both civil and criminal matters. Because there was no appellate jurisdiction granted in federal criminal prosecutions, any criminal matters would have to have been in the Supreme Court's original jurisdiction. Section 13 did provide the Supreme Court with exclusive original jurisdiction over criminal matters against ambassadors, other public ministers, and so on. But section 13 accomplished this by providing for Supreme Court exclusive jurisdiction of "suits or proceedings against . . public ministers." Id. § 13, 1 Stat. at 80 . 
against an alien, or by a citizen of the state in which the suit is brought against a citizen of another state, and the matter in dispute exceeds the aforesaid sum or value of five hundred dollars." 45 The imposition of an amountin-controversy requirement provides a strong indication that this language encompasses only civil cases. ${ }^{46}$ The remainder of the provision augments the strength of this supposition, requiring "surety" (in all cases) and "special bail" (in some cases), and setting forth the effect of "any attachment of the goods or estate of the defendant by the original process." 47 All of these procedural requirements suggest a limitation to civil cases. ${ }^{48}$ As the Pennsylvania Supreme Court unanimously opined when interpreting this section in 1798,

although the word 'suit' is used generally in the 12th section, without expressing the words 'of a civil nature,' yet the slightest consideration of what follows, manifestly shews that no other suit was meant; for the matter in dispute must exceed five hundred dollars in value, special bail must be given, \&c. terms applicable to actions of a civil nature only. ${ }^{49}$

Section 31 provides for substitution of an executor or administrator "where any suit shall be depending in any court of the United States, and either of the parties dies before final judgment," and the action survives. This provision uses "suit" to encompass civil cases only, for the prosecuting party in a criminal prosecution is not a natural person who can die (and therefore needs to be replaced), while the death of a criminal defendant terminates the prosecution (rather than resulting in continuation against a substitute).

The remaining intratextual evidence about the meaning of "suit" is mixed. But nothing plainly contradicts Hammond's claim that, all throughout the Judiciary Act, "the term suit is used in reference to a civil and not a criminal proceeding." 50

The strongest contrary textual argument is the use elsewhere in the Act of phrases such as "civil suit" and "suit of a civil nature." 51 The presence of these civil-only modifiers could suggest that, in their absence, "suit" would encompass not only civil suits and suits of a civil nature but also criminal suits

$45 \quad$ Id. $§ 12,1$ Stat. at 79.

46 See, e.g., United States v. More, 7 U.S. (3 Cranch) 159, 173-74 (1805) ("The words, 'matter in dispute,' seem appropriated to civil cases, where the subject in contest has a value beyond the sum mentioned in the act. But, in criminal cases, the question is the guilt or innocence of the accused. And although he may be fined upwards of [the amount-incontroversy requirement], yet that is, in the eye of the law, a punishment for the offence committed, and not the particular object of the suit.").

47 Judiciary Act $\$ 12,1$ Stat. at $79-80$.

48 'Special bail, also known as 'bail above' or 'bail to the action,' was based on persons promising to be responsible for the damages and costs assessed against a defendant if he lost in court and did not himself pay or surrender himself as a prisoner." 4 THE DOCUMENtary History of the Supreme Court of the United States, 1789-1800, at 242 (Maeva Marcus ed., 1992) [hereinafter 4 DHSC] (citations omitted).

49 Respublica v. Cobbett, 3 U.S. (3 Dall.) 467, 474-75 (Pa. 1798) (emphasis omitted).

50 Hampden X, supra note 33, at 53.

51 See, e.g., Judiciary Act $\S 11,1$ Stat. at 78-79. 
or suits of a criminal nature. ${ }^{52}$ There is also one candidate for the Judiciary Act's use of "suit" unmodified to include both civil and criminal cases. This is the use of "suit" at the end of section 9, which sets forth the original jurisdiction of federal district courts. Among other things, section 9 provided for exclusive district court jurisdiction over "crimes and offences" carrying punishments below certain levels, as well as "all suits against consuls or vice-consuls, except for offences above the description aforesaid." 53 The carve out from "all suits" of "offences" that carried a heavier punishment than those described earlier in the section suggests that "all suits" might otherwise encompass "all offences" in the absence of a carve out. ${ }^{54}$

Another intratextual comparison to note is the contrast between section 22's description of those circuit court cases the Supreme Court could review and section 25's description of those state court cases the Supreme Court could review. Section 22 authorizes review of "final judgments and decrees in civil actions, and suits in equity in a circuit court," 55 while section 25 authorizes review of "a final judgment or decree in any suit, in the highest court of law or equity of a State in which a decision in the suit could be had."56 One might argue that the transition in section 25 to "final judgment or decree in any suit" is designed to encompass more than "civil actions." 57 There is admitted force to this argument. But one might respond that the more relevant contrast is between section 25's "any suit, in the highest court of law or equity," and section 22's "suits in equity in a circuit court," such that section 25 expands the category of suits beyond equity rather than draws on a contrast between the narrower formulation "civil action" and the allegedly broader formulation "any suit."

In the end, there is only so much that one can make out from the intratextual evidence. When one casts a broader net in search of the ordinary meaning of the term at the time, however, one sees that "suit" was not ordinarily used to describe a criminal prosecution. That is, one would not

52 Robert Pushaw has argued, for example, that "[t] he Judiciary Act of 1789 . . uses 'civil' in every instance where Congress intended to limit jurisdiction to civil matters." Pushaw, supra note 20, at $870 \mathrm{n} .100$ (internal citations omitted). That claim is inconsistent with this Article's explication of "suit" as used in sections 12, 31, and 35.

53 Judiciary Act $\$ 9,1$ Stat. at 77 .

54 John Harrison has interpreted this language in a way that includes criminal prosecutions as "offences" within the carve out from "all suits." See Harrison, supra note 8, at 237 ("Although one might wonder whether suits include criminal prosecutions, the exclusion of criminal offenses with a punishment above the stated level strongly indicates that a prosecution with potential punishment below that level would be within the jurisdiction."). A potential line of response that requires further exploration is whether Harrison's assimilation of "offences" to "criminal prosecutions" is too hasty because there are some "offences" would have been addressed in civil actions. Some offences at the time could have been pursued via qui tam information, which would have been a civil action. And there were also some civil suits by government officials seeking penalties. McCulloch $v$. Maryland, for example, was a debt action.

55 Judiciary Act $§ 22,1$ Stat. at 84 .

$56 \quad I d$. at $85-87$.

57 I thank Jim Pfander for highlighting this argument for me. 
have typically described a proceeding initiated by indictment in 1789 as a suit. In this respect, not much has changed. No state prosecutor now will be overheard talking about a prosecution as a "suit."

Several scholars have previously contended that the distinction in Article III between the use of "cases" and "controversies" signals a difference between the broader category of "cases" that included both criminal and civil actions and the narrower civil-only category of "controversies." 58 Less well known, however, is a similar distinction between "cases" and "suits." This distinction appears in Judge Edmund Pendleton's opinion in the 1782 Virginia case of Commonwealth v. Caton. ${ }^{59}$ This case involved interpretation of a jurisdictional statute with three branches. The first branch used the term "suits," the second used "controversy" (and also included an amount-in-controversy requirement), while the third used "cases." Judge Pendleton reasoned that " $[\mathrm{i}] \mathrm{n}$ the two first branches, the terms suits and controversies are used, in terms proper to describe disputes between litigant parties, and would seem to exclude criminal cases ... . But, in the third branch, those terms are dropt, and the more general one of cases adopted." ${ }^{0}$ According to Pendleton, this more general term "cases" included both civil and criminal matters. ${ }^{61}$

This civil-only meaning of "suit" appears not only in the Judiciary Act, but also in the provisions that became the Sixth and Seventh Amendments, which were proposed for ratification by Congress one day after the Judiciary Act. The Sixth Amendment applies "[i]n all criminal prosecutions." 62 The Seventh Amendment, by contrast, applies "[i]n [s] uits at common law, where the value of the controversy shall exceed twenty dollars." 63 The Sixth Amendment covers criminal cases, while the Seventh Amendment does not. And a few years later, Congress used "suit" to encompass civil cases only when it drafted the language that became the Eleventh Amendment. That Amendment, which is an instruction about how to construe the jurisdictional grants

58 See, e.g., Harrison, supra note 8, at 221-30; Meltzer, supra note 21, at 1575; Pfander, supra note 18, at 604-09. Robert Pushaw critiques this civil/criminal distinction in Pushaw, supra note 20, at 864-73, and Robert J. Pushaw, Jr., Article III's Case/Controversy Distinction and the Dual Functions of Federal Courts, 69 Notre Dame L. Rev. 447 (1994). Pushaw contends instead that the two words "cases" and "controversies" identified two different judicial functions: "The federal courts' principal function in Article III 'Cases' was to expound laws having national and international significance, whereas their main role in 'Controversies' was to act as an impartial arbitrator." Pushaw, supra note 20, at 864-65. This Article does not take a position on who has the best of this debate with respect to the meaning of Article III. At a minimum, the evidence indicates that some important legal thinkers in the late eighteenth and early nineteenth centuries distinguished "controversies" and "cases" in a way that understood "controversies" to encompass civil cases only and "cases" also to include criminal cases.

598 Va. (4 Call) 5 (1782). I am grateful to Jim Pfander for steering me to this case.

60 Id. at 14 .

$61 \quad I d$.

62 U.S. Const. amend. VI.

63 Id. amend. VII. 
in Article III, applies to "any suit in law or equity." Its phrase "any suit" encompasses only civil cases, because the Eleventh Amendment's prohibition covers suits only if "commenced or prosecuted against one of the United States by [c]itizens of another [s] tate, or by [c]itizens or [s] ubjects of any [f] oreign [s] tate." 64

Another civil-only usage of "suit" to consider from the first Congress appears in the Process Act of 1789. In the Process Act, Congress generally provided that federal courts would adopt state procedures in "suits at common law." The Process Act, however, was not taken to regulate federal court procedure in federal criminal prosecutions. ${ }^{65}$

A final important civil-only usage of "suit" to consider is in the first federal officer removal statute, which was enacted in 1815. Congress enacted this law "to extend the Judiciary Act of 1789 to ensure enforcement of the federal customs laws in the face of [state court] decisions misconstruing federal law." 66 Although the problems behind the passage of this law were limited to civil cases, Congress provided for removal of both "suits" and "prosecutions." 67 Congress plainly used "prosecutions" to mean criminal prosecutions, as is evident from its prohibition on the state appealing an acquittal of a defendant in state court. ${ }^{68} \mathrm{~A}$ reasonable inference is that "suits" alone would have been limited to civil cases.

\section{B. "in the highest court of law or equity of a state in which a decision in the suit could be had"}

The next chunk of statutory text to consider limits the state court suits in which a writ of error is available from the Supreme Court of the United States to those suits in which there has been a final judgment or decree "in the highest court of law or equity of a state in which a decision in the suit

64 Id. amend. XI. The "prosecuted" language in the Eleventh Amendment was intended to sweep in cases that had already been commenced, to make clear that, upon ratification, then-pending suits within the description of the Amendment could not be continued in federal court.

65 See Julius Goebel, Jr., History of the Supreme Court of the United States: ANTECEDENTS AND Beginnings to 1801, at 618 (1971) (explaining that, in federal criminal cases, "procedural questions were argued and settled at Circuit on the basis of English common law precedents," with only "occasional reference to state statutes, and even rarer inquiries into what state practice might be").

66 Kenneth S. Rosenblatt, Removal of Criminal Prosecutions of Federal Officials: Returning to the Original Intent of Congress, 29 Santa Clara L. Rev. 21, 30 (1989).

6728 Annals of Cong. 758-61 (1814); see also 2 American State Papers: Finance 1802-15 § 435, at 881 (Walter Lowrie \& Matthew St. Clair Clarke, eds., Washington, Gales \& Seaton 1814) (noting that "limited as the general powers of the revenue officers appear to be, they are rendered still more inadequate by the terror . . . of being exposed to suits for damages").

6828 Annals of Cong. 758-61; see also Rosenblatt, supra note 66, at 31 n.39 (noting that "the text of the Act indicates that Congress intended 'prosecutions' to mean criminal prosecutions"). 
could be had."69 This provision ensures that the suit has received the fullest consideration available in the state system before the questions of federal law at issue in the suit become eligible for Supreme Court review. The provision had to be worded as it was because Congress recognized that different kinds of suits would receive different levels of consideration in the various state systems. While the wording is inclusive, it is also a pointer toward Congress's awareness of the diversity of systems for appellate review in the states. And many of those systems provided very limited appellate review in criminal cases.

The first clue that criminal cases stand differently from civil cases with respect to appeals comes from a feature of Cohens $v$. Virginia that sometimes puzzles people coming to the case for the first time today. That is the identity of the court from which the case came to the Supreme Court-the quarterly session court for Norfolk, Virginia. ${ }^{70}$ Virginia law did not then provide for any appellate review of that court's decision to fine the Cohen brothers $\$ 100$ plus expenses. While it is certainly possible that Congress drafted section 25 to provide for cases to proceed directly to the Supreme Court in this fashion, it is worth pausing over this feature of Cohens to consider how much of an outlier the sort of inter-system appellate review performed in that criminal prosecution was when viewed together with other state and federal provisions limiting appellate review in criminal prosecutions.

Today's interpreters inhabit a world in which Supreme Court appellate review of criminal matters from both federal and state courts is routine. But states in the late eighteenth century varied significantly in their respective approaches to appellate review in criminal cases, and the absence of as-ofright appellate review in some state systems was consistent with the limited availability of appellate review at common law. Moreover, the Judiciary Act of 1789 did not provide for Supreme Court appellate review of federal criminal cases; the D.C. Organic Act did not provide for Supreme Court appellate review of criminal cases from the D.C. circuit courts either; and Congress later followed the same pattern of not authorizing Supreme Court appellate review of criminal cases decided in territories. ${ }^{71}$

The lack of any intra-system appellate review in Virginia was noted shortly after the decision in Cohens, albeit for a different purpose. In later criticism of the Supreme Court decision, one of Chief Justice Marshall's most relentless critics, Judge Spencer Roane of Virginia, charged in one of his pseudonymous essays in the Richmond Enquirer that the path of the case from the borough court straight to the Supreme Court showed that the case was

69 Judiciary Act of 1789 , ch. 20, $§ 25,1$ Stat. 73, 85 (1789).

70 See Cohens v. Virginia, 19 U.S. (6 Wheat.) 264, 448 (1821) ("This cause came on to be heard on the transcript of the record of the Quarterly Session Court for the Borough of Norfolk, in the Commonwealth of Virginia ....”).

71 There are, of course, reasons why inter-system review would be warranted when intra-system review would not be. In particular, Congress reasonably could have intended such inter-system review as a way of providing federal protection for federal interests. This consideration is addressed in more detail infra Section II.A. 
"feigned" in some way. ${ }^{72}$ Taking note of this criticism, Chief Justice Marshall wrote a few days later to the Supreme Court's reporter, Henry Wheaton, asking him to add a footnote to the reported case stating that an appeal had been sought and refused. ${ }^{73}$ He wrote to Wheaton that

I hope it is not too late to make an asterisk at that part of the opinion which states it to be the judgment of a court of the last resort \& insert in a note some such words as these, "Cohens prayed an appeal from this judgement but it was refused on the principle that there was no higher tribunal which could take cognizance of the case." 74

Wheaton inserted the footnote as requested. ${ }^{75}$

While the Chief Justice's quick response to newspaper criticism of the opinion is interesting in its own right, the more notable feature of this episode for present purposes is to highlight the disjunction between the state and federal systems in providing for appellate review. If section 25 reached criminal prosecutions like this one, then it provided for greater inter-system review than was provided on an intra-system basis in Virginia itself. As far as research has revealed, however, this disjunction was not deemed worthy of comment at the time of enactment or in the lead up to or the aftermath of Cohens. Perhaps this was due to a belief that state prosecutions presented a need for Supreme Court (or some other federal court) review that federal criminal prosecutions did not present because federal criminal prosecutions already took place in a federal court. Or maybe everyone's attention was focused on constitutional jurisdiction instead of statutory jurisdiction.

The absence of intra-system appellate review for the Cohen brothers' conviction and fine in Virginia was not a quirk of that Commonwealth's law. Although the differing structure of state judiciaries (both synchronically and diachronically) makes deep generalizations about state practice in the late eighteenth century difficult, ${ }^{76}$ appellate review had long been limited in criminal matters. At common law, a writ of error was generally available for misdemeanor convictions but not available as of right for felony convictions. ${ }^{77}$ And as Hammond noted in his Hampden essays, Virginia was not

72 See Algernon Sidney, On the Lottery Decision: No. 2, Richmond EnQuirer, May 29, 1821, reprinted in 2 John P. Branch Historical Papers of Randolph-Macon College 91, 92-93 (William E. Dodd, ed., 1906).

73 See Letter of John Marshall to Henry Wheaton (June 2, 1821), reprinted in 9 THE Papers of John Marshall 150 (Charles Hobson, ed., 1998). Marshall would have been familiar with the course of proceedings in Cohens because the writ of error had been issued under his signature.

74 Id.

75 See Cohens, 19 U.S. (6 Wheat.) at 376 n.a ("The plaintiff in error prayed an appeal from the judgment of the Court of Hustings, but it was refused, on the ground that there was no higher State tribunal which could take cognizance of the case.").

76 See David Rossman, "Were There No Appeal": The History of Review in American Criminal Courts, 81 J. Crim. L. \& Criminology 518, 525 (1990).

77 See 4 Blackstone, supra note 37, at *391-92; see also Goebel, supra note 65, at 610 \& n.9 (describing the foregoing discussion by Blackstone as "the book learning about common law limitations upon the availability of the writ [of error] in criminal cases"). 
the only state that followed "the policy of restricting the operation of writs of error, in prosecutions for offences against the state."78 Finally, even when a criminal defendant could obtain a writ of error for state court appellate review, that review was much more limited than in appeals today. Writ of error review did not encompass any factual questions and was limited to certain legal defects appearing on the face of the record. ${ }^{79}$

Section 25's provision for review via writ of error, rather than an appeal (which would have allowed for reconsideration of questions of both fact and law), was a response to concern about the ability of the Supreme Court to revisit factual as well as legal questions. The Seventh Amendment's Reexamination Clause also addresses this concern by providing that, in certain suits, "no fact tried by a jury shall be otherwise re-examined in any [c] ourt of the United States, than according to the rules of the common law." 80 But while the Seventh Amendment was proposed by the same Congress that enacted the Judiciary Act of 1789 , it was only a proposal that had yet to be ratified.

Interestingly, the Sixth Amendment contains no provision about appellate review analogous to the Seventh Amendment's Reexamination Clause. The explanation cannot be that people were worried about Supreme Court appellate reexamination of fact only in civil cases; if the Court could exercise appellate jurisdiction over criminal prosecutions, the same worries would have been expressed. A more likely explanation is the anticipated absence of federal appellate review in federal criminal prosecutions, at least under the Judiciary Act of 1789. ${ }^{81}$ Whatever the reason for this difference between the Sixth and Seventh Amendments-namely, that only the Seventh addresses a concern about appellate review-the different treatment is consistent with different approaches to appellate review in civil and criminal cases at the time more generally.

Although Cohens is an odd case because it provided for federal intersystem appellate review when there was no state intra-system appellate review, that is not the only oddity about the case. Another unusual feature of Cohens is that the Supreme Court used section 25 to engage in federal inter-system appellate review in a category of case-criminal prosecutions-for which

78 Charles Hammond, No. VIII, in Review of the Opinion, supra note 15, at 42.

79 See Rossman, supra note 76, at 525.

80 U.S. Const. amend. VII.

81 In the context of arguing about the absence of constitutional authority for a federal common law of crimes, James Madison argued in 1800 that Article III's extension of the federal judicial power to "all cases, in law and equity, arising under" federal law was "manifestly confined to cases of a civil nature; and would exclude cases of criminal jurisdiction." James Madison, Mr. Madison's Report to the Virginia General Assembly, Jan. 7, 1800, in Virginia Commission on Constitutional Government, We the States: An Anthology of Historic Documents and Commentaries Thereon, Expounding the State and Federal ReLATIONSHiP 157, 191-92 (1964). In support of this claim, Madison argued not only that "[c]riminal cases in law and equity, would be a language unknown to the law," but also that the provision for Supreme Court appellate jurisdiction as to law and fact in cases of law and equity arising under the Constitution "clearly excludes criminal cases where the trial by jury is secured; because the fact, in such cases, is not a subject of appeal." Id. at 192-93. 
there would have been no federal intra-system appellate review. In fact, an important civil/criminal distinction that runs through the Judiciary Act of 1789 is its provision for federal intra-system appellate review by the Supreme Court of some civil cases but no criminal cases.

Section 22 of the Act explicitly authorized Supreme Court review of "final judgments and decrees in civil actions, and suits in equity in a circuit court," subject to a two thousand dollar amount-in-controversy requirement. ${ }^{82}$ There is no explicit provision in the Act one way or the other for writs of error with respect to federal circuit court criminal cases. ${ }^{83}$ But the Supreme Court determined in 1805 that section 22's "affirmative description of [the Court's powers] must be understood as a regulation, under the constitution, prohibiting the exercise of other powers than those described." 84 Later explaining the Judiciary Act of 1789's denial of Supreme Court appellate review in federal circuit court criminal cases, Justice Story wrote that "the denial of this authority proceeded upon great principles of public policy and convenience. If every party had a right to bring before this Court every case, in which judgment had passed against him, for a crime or misdemeanor or felony, the course of justice might be materially delayed and obstructed, and, in some cases, totally frustrated." 85

82 Judiciary Act of 1789, ch. 20, § 22, 1 Stat. 73, 84-85 (emphasis added) (providing that "final judgments and decrees in civil actions, and suits in equity in a circuit court, brought there by original process, or removed there from courts of the several States, or removed there by appeal from a district court where the matter in dispute exceeds the sum or value of two thousand dollars, exclusive of costs, [may] be re-examined and reversed or affirmed in the Supreme Court"). This provision further requires issuance of a citation signed by a judge sitting on a circuit court or a Supreme Court Justice, and it provides that "every justice or judge signing a citation on any writ of error . . . shall take good and sufficient security, that the plaintiff in error shall prosecute his writ to effect, and answer all damages and costs if he fail to make his plea good." $I d$. at 85 .

83 See Ex parte Kearney, 20 U.S. (7 Wheat.) 38, 42 (1822) (“[T]his Court has no appellate jurisdiction confided to it in criminal cases, by the laws of the United States. It cannot entertain a writ of error, to revise the judgment of the Circuit Court, in any case where a party has been convicted of a public offence.").

84 United States v. More, 7 U.S. (3 Cranch.) 159, 173 (1805). The jurisdictional law at issue in this case was the 1801 Organic Act of the District of Columbia. But the language quoted in the text above is a statement about section 22 of the First Judiciary Act. The decision in More and the significance of the Court's interpretation of the jurisdictional grant in the D.C. Organic Act are considered in more detail below.

85 Ex parte Kearney, 20 U.S. (7 Wheat.) at 42. Despite the absence of Supreme Court appellate review in federal criminal cases, the federal system nevertheless came to include a means for obtaining Supreme Court review of legal questions that arose in the course of such cases. The Judiciary Act of 1802 authorized the certification of questions to the Supreme Court when the circuit court was divided in its opinion. See Rossman, supra note 76 , at 563. This kind of certification was not available from state courts to federal courts, however, and it is probably anachronistic to even consider it to have been a live possibility. It was not until 1889 that Congress granted the right of appeal by writ of error in a criminal case, but this was only in capital crimes. See Lester B. Orfield, Early Federal Criminal Procedure, 7 WAYNe L. Rev. 503, 528-29 (1961). 
Given the absence of Supreme Court appellate review of federal circuit court criminal cases and the limited availability of appellate review by a state's highest court in state criminal cases, it is perhaps unsurprising that Congress in 1801 did not provide for Supreme Court appellate review of criminal cases when it first created the new circuit court for the District of Columbia. The D.C. Act gave the newly created circuit court for the District of Columbia cognizance of "all crimes and offences" committed in the district, "all cases in law and equity" involving at least one district resident, "all actions or suits of a civil nature at common law or in equity" in which the United States were "plaintiffs," and "all seizures on land or water, and all penalties and forfeitures made, arising or accruing under the laws of the United States." 86 The D.C. Act further provided that the Supreme Court could engage in appellate review (via writ of error or appeal) of "any final judgment, order or decree in said circuit court, wherein the matter in dispute, exclusive of costs, shall exceed the value of one hundred dollars." 87

Although there was no statutory language explicitly confining this appellate review to civil cases, the Supreme Court soon held that the appellate jurisdiction granted by the D.C. Act was "confined to civil cases." 88 On behalf of a unanimous Court, Chief Justice Marshall explained in United States $v$. More that for Congress to provide for appellate jurisdiction in this one class of cases was to exclude appellate jurisdiction in cases not mentioned: "as the jurisdiction of the court has been described, it has been regulated by congress, and an affirmative description of its powers must be understood as a regulation, under the constitution, prohibiting the exercise of other powers than those described." 89 Marshall next elaborated this principle with the example of section 22 of the First Judiciary Act, discussed above. Section 22 authorized the Supreme Court to issue a writ of error in federal circuit court cases in which the amount in controversy exceeded two thousand dollars. Marshall stated that Congress's grant of authority to review cases above that amount implied the denial of authority to review cases below that amount even though " $[\mathrm{t}]$ here are no words in the act restraining the supreme court from taking cognizance of causes under that sum."90 Marshall next enunciated the interpretive principle that " $[\mathrm{t}]$ his court, therefore, will only review those judgments of the circuit court of Columbia, a power to reexamine which, is expressly given by law."91 Appellate jurisdiction over D.C. circuit court criminal cases was not "expressly given by law," Marshall concluded, because " $[\mathrm{t}]$ he words, 'matter in dispute,' seem appropriated to civil cases." 92 He explained that, "in criminal cases, the question is the guilt or innocence of the accused. And although he may be fined upwards of 100 dollars, yet

86 An Act Concerning the District of Columbia, ch. 15, 2 Stat. 103, 106 (1801).

87 Id.

88 More, 7 U.S. (3 Cranch.) at 173.

$89 I d$.

$90 \quad I d$.

$91 \quad I d$.

92 Id. at $173-74$. 
that is, in the eye of the law, a punishment for the offence committed, and not the particular object of the suit."93

Although the foregoing context about limited availability of appellate review in criminal cases supports a civil-only interpretation of section 25, one could argue that the inclusive language discussed in this section actually cuts strongly the other way. The argument would be that this obviously inclusive language was used precisely so that there would be Supreme Court appellate jurisdiction over categories of cases like criminal prosecutions in which states did not provide for appellate review. ${ }^{94}$ This is a powerful argument, to be sure, but in support of an inference about criminal prosecutions, it runs into Congress's use of "prosecutions" in addition to "suits" when Congress specifically intended to include criminal prosecutions (in section 35) as well as the arguments against inferring inclusion of criminal prosecutions from silence about them. ${ }^{95}$

\section{C. "under the same regulations . . . as if the judgment or decree complained of had been rendered or passed in a circuit court"}

The Supreme Court's treatment of the D.C. court amount-in-controversy requirement in United States $v$. More provides a window into the meaning of section 25's language providing for the issuance of a writ of error "in the same manner and under the same regulations . . . as if the judgment or decree complained of had been rendered or passed in a circuit court." As previously noted, the Judiciary Act of 1789 nowhere authorized the Supreme Court to issue a writ of error to a federal circuit court in a criminal case. And with respect to Supreme Court appellate review of civil cases in the federal circuit courts-addressed in section 22-Congress provided a two thousand dollar amount-in-controversy limitation. As More instructs, such a limitation is a "regulation" of jurisdiction. The question then becomes: Did Congress incorporate section 22's amount-in-controversy requirement into section 25 by means of the requirement that writs of error be issued to state courts "under the same regulations" as to circuit courts?

The idea that section 25's "under the same regulations" language may have incorporated section 22's amount-in-controversy requirement does not appear to have been addressed by anybody since the 1820s. As a doctrinal matter, the Supreme Court killed the idea in its 1823 decision of Buel v. Van Ness. ${ }^{96}$ The Supreme Court held in Buel that section 25's "in the same manner, and under the same regulations" language did not incorporate the amount-in-controversy limitation of section 22. ${ }^{97}$ Writing for the Court, Justice Johnson stated that incorporating section 22's amount-in-controversy

\footnotetext{
$93 \quad I d$. at 174.

94 I am indebted to A.J. Bellia for highlighting the force of this objection.

95 The section 35 argument is addressed in Section I.A above, and the arguments about inferences from silence are addressed in Section II.A below.

9621 U.S. (8 Wheat.) 312 (1823).

$97 \quad I d$. at 318.
} 
limitation into section 25 via the "same regulations" language of that provision ignores the context of this language:

It is obvious from the context, as well as from its ordinary meaning and use, that its proper bearing is altogether confined to the writ of error, citation, $\& c$. to be issued in a case which has been before fully defined, and not that it should itself enter into the descriptive circumstances by which those cases are to be identified, to which the appellate jurisdiction of the Court is to be extended. ${ }^{98}$

Justice Johnson also appealed to the different purposes of section 22 and section 25: "Questions of mere meum and tuum, are those to which the $22 \mathrm{~d}$ section relates; but those intended to be provided for by the 25th section, are noticed only for their national importance, and are deemed proper for an appellate tribunal, from the principles, not the sums, that they involve."99

Justice Johnson's reasoning in Buel has some force to it. But it is more persuasive with respect to "same manner" than "same regulations," and it is far from conclusive. Even though section 22 and section 25 admittedly have somewhat different purposes, Justice Johnson's opinion in Buel does not address just which "regulations" from section 22 are incorporated by section 25's language if not the amount-in-controversy requirement. Consider, for example, the requirement for the justice signing the writ of error to "take good and sufficient security, that the plaintiff in error shall prosecute his writ to effect, and answer all damages and costs if he fail to make his plea good." 100 Is this a regulation of jurisdiction incorporated from section 22 into section 25? If so, how would it apply in a criminal case?

Consider, also, Justice Johnson's separate opinion in Martin v. Hunter's Lessee, decided just five years before Cohens. In that case, Justice Johnson explicitly differentiated between the Supreme Court's ability to review state court decisions in civil cases and in criminal cases. Although agreeing with the rest of the Court that section 25 authorized the Supreme Court to engage in appellate review via writ of error to state courts in civil cases, Johnson stated that " $[\mathrm{t}]$ he courts of the United States are vested with no power to scrutinize into the proceedings of the state courts in criminal cases."101 $\mathrm{He}$ observed that "[a]t present the uncontrollable exercise of criminal jurisdiction is most securely confided to the state tribunals." 102 Justice Johnson's opinion seemingly left open the possibility that such jurisdiction would be within the constitutional power of Congress to grant, but he wrote that "[a]t present it is only necessary to vindicate the laws which [the general government has] passed affecting civil cases pending in state tribunals." 103 Neither in Cohens nor in Buel (nor anywhere else uncovered by research) does Justice Johnson explain how his views about Supreme Court jurisdiction to engage

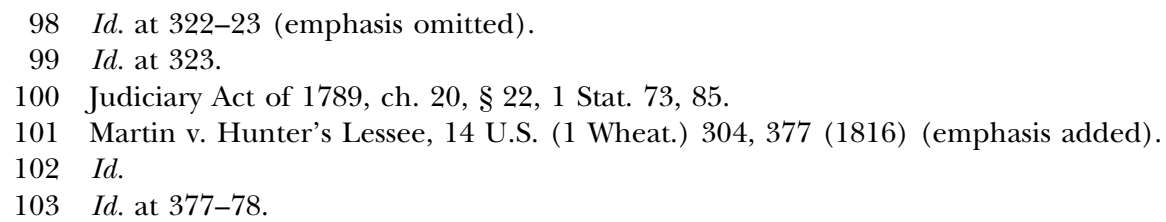


in appellate review of state court criminal prosecutions had changed between 1816 and 1821. Nor has anyone else offered an argument justifying Justice Johnson's switch.

Justice Johnson was not alone in his 1816 civil-only understanding of section 25. Writing to the Chairman of the House Ways and Means Committee near the end of 1814, Alexander Dallas-the first (unofficial) Supreme Court reporter, Secretary of the Commonwealth in Pennsylvania from 1791 to 1801, United States Attorney in the Eastern District of Pennsylvania from 1801 to 1814 , Secretary of the Treasury from 1814 to 1816 , and acting Secretary of State and Secretary of War for several months in 1815-went even further than Johnson in a civil-only understanding of section 25. Dallas expressly interpreted section 25 to incorporate section 22's two thousand dollar amount-in-controversy requirement. This issue was important to Dallas because he was seeking legislation that would authorize removal of certain actions from state court into federal court. The immediate problem that Dallas needed removal authority to address was difficulty enforcing federal revenue laws in Vermont. As Dallas explained, the general powers of federal revenue officers to deal with smuggling were limited, and those powers were

rendered still more inadequate by the terror which the officers now feel, of being exposed to suits for damages, under the authority of recent decisions in the courts of law; for it has been adjudged in Vermont, that the inspectors of the customs are not authorized, in any case, to make seizures, and that actions may be maintained against them, to recover the whole value of the property seized, even when the property itself has been duly condemned, as forfeited by law. ${ }^{104}$

In explaining why new removal authority was necessary, Dallas described existing legal protections as inadequate. Among those legal protections was Supreme Court appellate review via writ of error, but as Dallas described this provision, "the matter in dispute must exceed the value of two thousand dollars, exclusive of costs." 105

Although Dallas's reading of section 25 differed from the reading eventually adopted by the Supreme Court in Buel, his apparent understanding of the legal effect of "under the same regulations" language was vindicated in a later decision by the Supreme Court involving that same language in a different statute. We have already seen that Congress did not provide for Supreme Court appellate review of federal criminal cases or criminal cases in the D.C. courts. Congress followed the same pattern when it provided for Supreme Court authority to issue writs of error to territorial courts (as in Utah, Washington, and Montana, for example). The jurisdictional statutes for the territories, like the jurisdictional statute for the District of Columbia, provided that the Supreme Court was to review the judgments and decrees of these courts "in the same manner and under the same regulations" provided as to

104 Letter from A.J. Dallas to J.W. Effes (Nov. 19, 1814), reprinted in 3 American State Papers (Finance) (Walter Lowrie \& Matthew St. Clair Clarke, eds., Washington, Gales \& Seaton 1814) 881, 881-82.

$105 I d$. 
the final judgments and decrees of the federal circuit courts. ${ }^{106}$ In the 1889 case of Farnsworth $v$. Montana, the Supreme Court interpreted this language to encompass the amount-in-controversy regulations, which in turn excluded criminal cases from review:

In all these prior statutes . . . it was said that this court was to review the judgments and decrees "in the same manner and under the same regulations" provided as to the final judgments and decrees of a Circuit Court. These prior provisions are not repealed, and no jurisdiction ever existed in this court to review by writ of error or appeal the judgment of a Circuit Court in a criminal case. ${ }^{107}$

In deciding Farnsworth in 1889, the Supreme Court seemed to be unaware of its decision more than six decades earlier in Buel v. Van Ness. Consequently, the Court did not attempt to square its straightforward reading of "in the same manner, and under the same regulations" in the territorial jurisdictional statute with its earlier contrary reading of the same language in section 25.

Farnsworth's holding regarding the absence of Supreme Court review of territorial criminal cases may be surprising to constitutional lawyers today whose familiarity with territorial cases comes primarily from the Supreme Court's 1878 decision in Reynolds v. United States. ${ }^{108}$ After all, the Supreme Court decided Reynolds on a writ of error to the Supreme Court of the Territory of Utah in a criminal prosecution for violating a federal bigamy prohibition. ${ }^{109}$ If the Supreme Court did not possess authority to issue writs of error in criminal cases arising out of the territories, one might wonder how it had authority to decide Reynolds. As it turns out, Congress had enacted a special jurisdictional statute authorizing review of certain criminal cases from Utah, namely those "where the accused shall have been sentenced to capital punishment, or convicted of bigamy or polygamy." 110 Absent that statute, the Supreme Court could not have addressed the Free Exercise Clause issue that it decided in Reynolds. In the later-decided case of Snow v. United States (which involved cohabitation, but not bigamy or polygamy), the Supreme Court explained that this special jurisdictional provision was inapplicable and the Court was otherwise unauthorized to exercise jurisdiction to review a criminal prosecution. ${ }^{111}$

\section{D. "may proceed to a final decision of the same, and award execution"}

There is a final piece of statutory text to consider in section 25. After providing that "the writ shall have the same effect" when issued in a state

106 Farnsworth v. Montana, 129 U.S. 104, 113-14 (1889) (internal quotations omitted).

107 Id. at 113.

10898 U.S. 145 (1878).

109 Id. at $150-51$.

110 Snow v. United States, 118 U.S. 346, 349 (1886) (describing the provisions of the special jurisdictional statute).

111 Id. at 351-54. 
court case, "as if the judgment or decree complained of had been rendered or passed in a circuit court," 112 section 25 authorizes the Supreme Court to "proceed to a final decision" and "award execution" instead of remanding for final decision, but only if "the cause shall have been once remanded before." 113

This statutory language seems to contemplate civil cases only. If a criminal defendant prevails on a federal law ground at the Supreme Court after losing in the state court, the appropriate remedy might be something like release from prison or a new trial, but the Supreme Court was given no authority to issue these kinds of remedies when hearing cases via writ of error in state court cases. Moreover, the evident purpose of allowing the Supreme Court to "proceed to a final decision" and "award execution" in cases that had previously been remanded was to ensure judgment without reliance on a balky state court. ${ }^{114}$ It is unclear how that purpose could be served with respect to a state court that refused to conduct a new trial or to order release from imprisonment. ${ }^{115}$

One possibility may be that Congress believed the Supreme Court could use its section 14 authority to issue writs in aid of its jurisdiction in order to grant a writ of habeas corpus after jurisdiction attached under section 25. ${ }^{116}$ The principal difficulty with this argument is overcoming section 14's explicit statement that the Supreme Court's grant of a writ of habeas corpus was limited to prisoners who are "in custody, under or by colour of the authority of the United States, or are committed for trial before some court of the same, or are necessary to be brought into court to testify." 117

Section 25's evident concern about Supreme Court mandates to less than cooperative state courts was no minor matter. By instructing that the writ of error should have the same effect in cases from the state courts and circuit courts, section 25 incorporated section 24's directive that "the Supreme Court shall not issue execution in causes that are removed from

\section{Judiciary Act of 1789 , ch. 20, § 22, 1 Stat. 73, 80.}

113 Id. This was authority that the Supreme Court used, for example, to get around Virginia's intransigence in Martin v. Hunter's Lessee, 14 U.S. (1 Wheat.) 304, 323-24 (1816).

114 See Goebel, supra note 65, at 481 (explaining that this provision "was apparently devised to meet the situation where a judgment or decree of the Supreme Court would not be executed by a state court and supplementary proceedings in error were brought"). This problem was apparently familiar to the Judiciary Act's principal draftsman and sponsor, Oliver Ellsworth, who had experienced it in a couple of cases when he was on the standing committee for hearing prize appeals. See id.

115 This argument was first advanced by Charles Hammond in his Hampden Essay X. See Hampden X, supra note 33, at 55 ("In a criminal prosecution, the defendant in the state court, the plaintiff in error in the Supreme Court of the United States, may be imprisoned under the judgment reversed-he may stand underneath the gallows, as it were, at the time of reversal-What execution, in such case, could be awarded? Surely, if the framers of the act had intended to embrace criminal proceedings, they would have provided for the liberation of the party whom the judgment of reversal pronounced innocent.").

116 I thank Jim Pfander for alerting me to this possibility.

117 Ch. 20, § 22, 1 Stat. at 81-82. 
them by writs of error, but shall send a special mandate to the circuit court to award execution thereupon."118 In providing a way around this "special mandate" method for cases from the state courts, Congress addressed a concern that the Supreme Court's mandate would not necessarily be viewed as mandatory by state courts. And that concern may not have stemmed from a simple worry that state courts would act unlawfully, but rather from the belief that the Supreme Court did not have authority to mandate state courts to award execution. This was, of course, one of the central issues in Martin $v$. Hunter's Lessee, but that case was almost three decades away when the Judiciary Act was enacted. And the principal point of Justice Johnson's separate opinion in Martin is a disclaimer of this kind of Supreme Court authority over state courts:

$[\mathrm{T}]$ he court disavows all intention to decide on the right to issue compulsory process to the state courts; thus leaving us, in my opinion, where the constitution and laws place us-supreme over persons and cases as far as our judicial powers extend, but not asserting any compulsory control over the state tribunals.

As Johnson went on to explain,

the framers of [Section 25] plainly foresaw that the state courts might refuse; and not being willing to leave ground for the implication, that compulsory process must be resorted to, because no specific provision was made, they have provided the means, by authorizing this court, in case of reversal of the state decision, to execute its own judgment. ${ }^{119}$

The Supreme Court did not face such a situation in Cohens because it affirmed the Virginia convictions. But perhaps it is no coincidence that the most famous comment about the inability of the Supreme Court to enforce its own judgments came in a state criminal prosecution. In Worcester v. Georgia, the Supreme Court reversed the Georgia conviction of Samuel Worcester for preaching on Indian lands in Georgia without a license from the state. ${ }^{120}$ Lore has it that Andrew Jackson said of this decision that "John Marshall has made his decision, now let him enforce it." 121 As it turns out, this lore has

$118 I d$. at 85.

119 Hunter's Lessee, 14 U.S. (1 Wheat.) at 366 (opinion of Johnson, J.). Justice Johnson also explained that this concern was only posed by reversals, not affirmances, and he linked this portion of section 25 with the scope of mandamus authority granted the Supreme Court in section 13. See id. ("In case of reversal only was this necessary; for, in case of affirmance, this collision could not arise. It is true, that the words of this section are, that this court may, in their discretion, proceed to execute its own judgment. But these words were very properly put in, that it might not be made imperative upon this court to proceed indiscriminately in this way; as it could only be necessary in case of the refusal of the state courts; and this idea is fully confirmed by the words of the 13th section, which restrict this court in issuing the writ of mandamus, so as to confine it expressly to those courts which are constituted by the United States.").

120 Worcester v. Georgia, 31 U.S. (6 Pet.) 515 (1832).

121 Justin Crowe, Building the Judiciary 111 (2012). 
never been verified. ${ }^{122}$ But whether President Jackson made this statement or not, it remains the case that the Supreme Court lacked the ability to ensure that state courts actually carried out the Court's judgments. This was a problem that Congress had recognized and sought to address, but with means designed for civil but not criminal cases.

\section{Objections and Replies}

The affirmative case for civil-only section 25 developed up to this point has been largely, but not exclusively, textual. This textual exposition has already addressed some alternative readings and considered some of the evidence for contrary interpretations of the statutory text. But there is more to the cases for and against civil-only section 25 than the prior Part's clause-byclause consideration has thus far revealed. This Part now takes a broader view and addresses three of the most powerful objections to a civil-only interpretation of section 25 .

A first objection (or cluster of objections) relates to statutory structure, statutory purpose, and consequences. The first Congress obviously recognized that state court decisions could undercut the supremacy and uniformity of federal law. Given that this problem would not be limited to civil cases and that section 25 was Congress's way of addressing it, it would make no sense to limit section 25's reach to civil cases only. A second objection is that the civil-only interpretation of section 25 is too novel or surprising. If Congress had really limited section 25 to civil cases only, we would not be finding this out two hundred twenty-five years later. A third objection is that a civilonly interpretation of section 25 would mean that Congress acted unconstitutionally by failing to vest some federal court with either original or appellate jurisdiction in all cases arising under federal law.

The responses to each of these objections vary from each other in their specifics. But they have a common thrust, which is to point out how the objections themselves are rooted in ways of thinking that take for granted the world that Cohens v. Virginia helped to create.

\section{A. The Objection that Civil-only Section 25 Undercuts Federal Protection for the Uniformity and Supremacy of Federal Law}

We begin with the observation that civil-only section 25 would have left a hole the size of all state criminal prosecutions in Supreme Court appellate review. This leads to an obvious question: Could Congress (possibly or actually) have intended that? After all, section 25 prudently provided for Supreme Court appellate review of state court decisions in which the state court decided a question of federal law against someone claiming the protection of federal law. Why would Congress have provided this type of review for civil cases only? Put another way, what reason is there to think that Congress

122 Id. (describing President Jackson's purported statement as "almost certainly apocryphal"). 
excluded from the Supreme Court's appellate jurisdiction the review of federal questions decided against someone invoking the protection of federal law in state court criminal cases while securing such review in state court civil cases?

The first point to acknowledge is that an explicit distinction between civil cases and criminal cases in connection with the scope of review under section 25 issue never came up in any prominent way during Congress's consideration of the Judiciary Act of 1789. The only explicit recorded discussion of the potential for a state court criminal prosecution to override a federallaw-based defense that research has revealed was about the possibility of a state prosecution for violation of an unconstitutional ex post facto law. ${ }^{123}$ Interestingly, the congressman discussing this possibility relied not on Supreme Court appellate review as a corrective, but instead on the state judges' obligation to abide by their oath to uphold the Constitution. ${ }^{124}$ The most explicit documentary evidence against a civil-only interpretation may be a letter written by Senator Caleb Strong (one of the Act's drafters) describing the scope of Supreme Court review in a way that differentiated between civil and criminal cases for Supreme Court review of federal circuit court decisions, but not for state court decisions. ${ }^{125}$ It is unclear, though, whether Strong meant to distinguish on these grounds rather than to describe the provisions of the Act in a general fashion. ${ }^{126}$

One reason for the limited discussion of section 25 overall is that the primary debates over the Act dealt not with the availability of appellate review of state courts, but the desirability of an extensive system of lower federal courts. ${ }^{127}$ Everyone acknowledged the need for lower federal courts in admiralty cases, but opponents of the Act argued that such courts were unneces-

123 See Statement of Rep. Jackson (August 29, 1789), in 9 Documentary History of the First Federal Congress 1789-1791: Debates in the House of Representatives, First SesSion, June-September 1789, at 1360 (Charlene Bangs Bickford et al. eds., 1992) [hereinafter First Session Debates].

$124 I d$.

125 See Letter from Caleb Strong (May 24, 1789), in 4 DHSC, supra note 48, at 395, 398 ("Writs of Error from the Circuit to the Supr. Court in all Causes not criminal of which the Circuit Court has original Cognizance and the Matter in Dispute does not exceed 2000 Dolrs. If a Cause in a State Court the Question is whether a Law of the State or of the United States is constitutional and the Judgment is in favor of the State Law or against the Law of the U.S. a Writ of Error will lie to have that Question \& that only determined in the Supreme Court. $[\mathrm{N}] \mathrm{o}$ other power in the federal Courts to revise Judgments in the State Courts.").

126 Strong's generalizations were not entirely accurate even in this section. In describing section 25 review, for example, he limited it to state court decisions of constitutionality, when the provision by its terms reached more broadly. $I d$.

127 See 4 DHSC, supra note 48, at 30-31 ("[O]pposition to the bill centered on the proposal to establish a system of federal inferior courts, and the extent of inferior federal court jurisdiction was an issue that arose almost immediately on the Senate floor."). "The primary debate over the Judiciary Act in the House of Representatives-whose records, unlike the Senate's, have been largely preserved-was over a motion introduced by Samuel Livermore of New Hampshire to eliminate the Senate bill's provision to create federal 
sary for law and equity cases. ${ }^{128}$ They contended that decision by state courts with review by the Supreme Court was preferable to decision by lower federal courts. Given this opposition strategy, it is understandable that opponents of the Act did not emphasize any particular limits on the types of state court cases in which the Supreme Court would exercise appellate review.

Awareness of the way in which opponents of an extensive system of inferior federal courts relied on the availability of appellate review of state courts enables one to contextualize some of the broadest statements about the availability of section 25 appellate review. Representative Jackson of Georgia, for example, proffered a broad reading of the provision: "Sir, in my opinion, and I am convinced experience will prove it, there will, nor can be no suit or action brought in any of the State courts but may under this clause be reversed or affirmed by being brought within the cognizance of the supreme court."129

Yet in the very next sentence after this one, Representative Jackson made clear that there were some exceptions to the Court's jurisdiction at present; his claim was that these limits would eventually be lost. ${ }^{130}$

Given Congress's seeming extratextual silence on a civil/criminal distinction in section 25, one question for an interpreter seeking clues outside the statutory text is which way this silence cuts. Given the near-universal assumption now (and for almost two centuries) that section 25 treats civil suits and criminal prosecutions alike, one tendency may be to view extratextual silence as cutting against a civil-only interpretation. But while this tendency is understandable, is it justified? Two reasons to think not-that is, two reasons to think that extratextual silence should cut against treating Supreme Court appellate review of civil suits and criminal prosecutions alike-is that Supreme Court appellate review of these two types of cases would have been understood differently in light of two other pieces of surrounding law.

The first of these is the background legal principle that one sovereign will not enforce the penal laws of another absent a clear statement. The standard citation for this principle is St. George Tucker's 1803 formulation:

district courts, except perhaps for admiralty matters.” Michael G. Collins, The Federal Courts, the First Congress, and the Non-Settlement of 1789, 91 VA. L. REv. 1515, 1523 (2005).

128 See 4 DHSC, supra note 48, at 31 (describing the proposed amendment by Virginia's Richard Henry Lee, who "moved to limit the jurisdiction of the inferior federal courts to admiralty and maritime cases and to limit 'federal interference' to 'Appeal only from the State Courts' to the Supreme Court").

129 See First Session Debates, supra note 123, at 1361.

$130 I d$. at 1361-62 ("But should there be some exceptions for the present, yet Sir, the precedent is so forcible, for it goes so far as even to admit of constructions that under some construction or other, of some of the articles, those articles will in time be totally lost."). Jackson's explicit acknowledgment of some "exceptions" to the Supreme Court's appellate jurisdiction undercuts Professor Amar's contrary interpretation that "[f] or Jackson, at least, section 25 was plenary, and covered all arising under cases." Amar, supra note 5, at 1558. 
[T] he cognizance of every crime and misdemeanor, whatsoever, committed within the body of any state, belongs to the courts of that state, in which the offense is committed, exclusively; unless it can be shewn that a power over the subject hath been expressly granted to the United States, by the federal constitution. ${ }^{131}$

Although Tucker was writing about a different subject than Supreme Court appellate review of state criminal prosecutions (he was arguing against a federal common law of crimes), his formulation of this clear statement rule would encompass Supreme Court appellate review of state criminal prosecutions because subjecting these prosecutions to federal review would destroy state exclusivity. If the states had agreed to depart from this default by authorizing federal review of state court criminal prosecutions for violations of state law that implicated federal questions, such a departure likely would have been widely discussed and likely would have been accomplished expressly. ${ }^{132}$

And this consideration leads to the second background legal rule, which is the express text of Article III. After setting forth the categories of cases or controversies to which the federal judicial power shall extend, Article III distributes the jurisdiction of the Supreme Court between original and appellate jurisdiction. ${ }^{133}$ This distribution stipulates that the Supreme Court should have original jurisdiction over cases "in which a state shall be party." Given that the state is a party in criminal prosecutions, an extension of section 25 to criminal prosecutions would have placed in the Supreme Court's appellate jurisdiction a category of cases that Article III distributes to the Supreme Court's original jurisdiction. Perhaps this would have been constitutionally permissible for the reasons later given by Chief Justice Marshall in Cohens even though they are contrary to his earlier interpretation of the Distribution Clause in Marbury v. Madison. But Cohens was over three decades in the future. As of 1789, the potential constitutional difficulty with the extension of Supreme Court appellate jurisdiction to encompass state criminal prosecutions should have been apparent. And yet nobody made an objection along these lines.

In light of this surrounding law, one reasonable inference from Congress's extratextual silence on Supreme Court appellate review of state criminal prosecutions is that nobody believed section 25 authorized such jurisdiction. But because there are other reasonable inferences one can draw

1315 St. George Tucker, Blackstone's Commentaries: With Notes of Reference, to the Constitution and Laws of the Federal Government of the United States and of the Commonwealth of Virginia App. Note A 10 (1803); see also Anthony J. Bellia Jr., Congressional Power and State Court Jurisdiction, 94 GEO. L.J. 949, 959-64 (2006) (describing the general law principle that penal actions are local).

132 See Tucker, supra note 131, at App. Note A 10.

133 U.S. Const. art. III, § 2, cl. 2 ("In all cases affecting ambassadors, other public ministers and consuls, and those in which a state shall be party, the Supreme Court shall have original jurisdiction. In all the other cases before mentioned, the Supreme Court shall have appellate jurisdiction, both as to law and fact, with such exceptions, and under such regulations as the Congress shall make."). 
as well, it is worth moving beyond legal principles and thinking about practical considerations that may have shaped Congress's intentions for section 25 review. The discussion that follows addresses these practical considerations as a general matter from the point of view of 1789 and then turns to specific evidence about how these practical considerations fit into Congress's shaping of the Judiciary Act of 1789.

Let us first consider space and time. Geography was an important and pervasive consideration in the design of the new federal judicial system. As Congress considered the Judiciary Act of 1789, it was unclear where the Supreme Court would sit. ${ }^{134}$ But wherever that would turn out to be (if indeed there was to be just one place, which also was not settled), the Court at any given time would be far away from many people and places. ${ }^{135}$ There were no planes, trains, or automobiles; there was no telephone or telegraph. Supreme Court appellate review would necessarily take weeks or months. And while these geography-based considerations of space and time would obviously affect all cases, not just criminal cases, the two kinds of cases are not created alike. Civil cases are largely about money and property, while criminal cases are more often about liberty (and sometimes, life). Delay is more tolerable and more fixable with regard to money and property than liberty (or life). Also, civil cases are about righting private wrongs, which can be done over a longer time unlike righting public wrongs, which should be rectified quickly if they are to be rectified at all. ${ }^{136}$

Now consider expense, again from the point of view of Congress in 1789. Congress would have known that Supreme Court appellate review would be expensive, not only because of space and time considerations (which would have been more significant in 1789) but also because another layer of litigation adds another layer of expense (which remains true today despite improvements in transportation and technology). Like space and time, expense-related constraints would affect both civil and criminal cases. But, here too, such constraints would play out differently in civil and criminal cases because appellate review in civil cases, unlike in criminal cases, could be limited via an amount-in-controversy requirement confining Supreme Court appellate review to cases where there was a lot of money at stake. That is, after all, what Congress uncontroversially did for cases that originated in federal courts; the Judiciary Act did not provide for appellate review of federal criminal prosecutions and imposed a two thousand dollar amount-in-controversy requirement for Supreme Court appellate review of civil cases. And as explained above, moreover, there is good reason to believe that Congress treated state court cases similarly by incorporating section 22's amount-incontroversy requirement into section 25 .

134 Debates over the possible location of the nation's capital in the first Federal Congress took place while the Judiciary Act was being debated.

135 For a discussion of the influence of uncertainty about location on thinking about jurisdiction, see Pfander, supra note 18, at 568-72.

136 I thank Marc DeGirolami for drawing my attention to this point. 
Another consideration is the relative paucity of federal law issues that would have arisen in state criminal prosecutions in the early republic. This is an important and underappreciated aspect of the problem. Even if section 25 had left a hole in federal judicial protection for the uniformity and supremacy of federal law, the hole was a small one. Although federal law is now pervasive in state criminal prosecutions, in 1789 there were very few federal law issues that Congress would have anticipated arising in state criminal prosecutions. Constitutional limits on states in criminal prosecutions were relatively few prior to incorporation. ${ }^{137}$ Indeed, all of the "big" modern cases involving Supreme Court direct appellate review of state criminal prosecutions mentioned in the introduction are about rights that were later incorporated against the states but inapplicable in state prosecutions until then. And while clashes of regulatory authority like that at issue in Cohens were anticipated, Congress may not have anticipated that they would come to a head in criminal prosecutions rather than in civil suits.

A final consideration is that Supreme Court appellate review would have been only one tool among others that Congress could have used to address potential problems for federal law that might arise out of state criminal prosecutions. Given the variety of means Congress could have used to provide federal judicial protection for federal interests, it is a mistake to infer the necessity of one particular means (Supreme Court appellate review) from the desirability of the end alone.

The most obvious alternative to federal appellate review would have been original jurisdiction in a federal court. And one way of accomplishing that would have been pretrial removal of state criminal prosecutions. That is how Congress protected federal officers in the first federal officer removal act, enacted in 1815. ${ }^{138}$ And as noted above, Congress provided in that statute for removal of both "suits" and "prosecutions" against certain federal revenue officers. Although Congress did not provide for removal of state criminal prosecutions in the Judiciary Act of 1789, Congress did provide for removal of suits against aliens subject to an amount-in-controversy requirement of five hundred dollars. ${ }^{139}$ This shows congressional awareness of pretrial removal as a tool. And it was a more powerful tool than appellate review. By providing a federal forum for trial, pretrial removal would provide much greater protection for federal interests than would appellate review via writ of error, particularly because such review was limited to questions of law and thus would have left much unreviewable.

Another way that Congress could have protected federal interests through original federal jurisdiction is by criminalizing interference with federal functions. A prosecution for violating this federal criminal prohibition then could have been pursued in a federal court. This is how Congress dealt with the possibility that states would prosecute foreign ambassadors in state

137 The prohibition on ex post facto laws comes to mind, but nothing else, and even this prohibition was not explicitly limited to criminal laws.

138 See Act of Feb. 4, 1815, ch. 31, § 8, 3 Stat. 195, 198-99.

139 See Judiciary Act of 1789, ch. 20, $\S 22$, 1 Stat. 73, 79-80. 
court contrary to the exclusive federal jurisdiction over such prosecutions provided in the Judiciary Act. Sections 25 and 26 of the 1790 Crimes Bill provided for a punishment of up to three years' imprisonment for (among other things) prosecuting an ambassador, public minister, or their servants, or bringing legal process to bear on their goods. ${ }^{140}$

We now turn from general considerations of geography, expense, the extent of federal law, and Congress's alternatives in the abstract to a more specific exploration about how these considerations actually played out in connection with the enactment of section 25 in the Judiciary Act of 1789.

The paradigm case for section 25 review in the eyes of the Act's architect and the author of section 25, Senator Oliver Ellsworth, was a particular kind of civil case-those involving foreigners. An August 1789 letter by Congressman William Loughton Smith relates a personal conversation in which Ellsworth explained to him that section 25 was primarily for the benefit of foreigners whose claims might otherwise have been treated unfairly. ${ }^{141}$ By its terms, section 25 review extended more broadly than to claims of foreigners, of course. And while it would be inappropriate to limit the provision's reach to such claims by pointing to one narrow purpose behind the provision, it is also helpful to recognize that the paradigm case for section 25 review, in Ellsworth's view, involved foreigners.

Among cases involving foreigners, the cases of British creditors played an outsized role in influencing the shape of federal jurisdiction provided by

140 See Crimes Act of 1790, ch. 9, §§ 25-26, 1 Stat. 112, 117-18.

141 See Letter from William Loughton Smith to Edward Rutledge (Aug. 9-10, 1789) reprinted in 4 DHSC, supra note 48, at 498-99 ("Where is drawn in question the Validity of a Treaty \&ca. you think the appeal should be reciprocal . . . . The reason on which the Clause is grounded is that a citizen can't complain if his own State Court decides against him; that this Bill does not put him in that respect in a worse plight than he was before: on the other hand the Clause is absolutely necessary for the preservation of the federal government. There is much weight in your observation \& I am not clear but you are right: my opinion is not fixed. Mr. Elsworth who was principally concerned in drawing the Bill is a Judge of the State of Connecticut of much reputation for legal knowledge: he is a man of remarkable clearness of reasoning \& generally esteemed a person of abilities. I met him last night \& took notice of some of your objections which he endeavoured to refute. $\mathrm{He}$ observed that the convention had in view the condition of foreigners when they framed the Judicial of the U. States. The Citizens were already protected by [the State] Judges \& Courts, but foreigners were not. The Laws of nations \& Treaties were too much disregarded in the several States-Juries were too apt to be biased against them, in favor of their own citizens \& acquaintances: it was therefore necessary to have general Courts for causes in which foreigners were parties or citizens of different. States; hence arises this partiality which offends you: perhaps it may be carried too far."). On Founding-era concerns about state violations of and failures to enforce the law of nations more generally, see Anthony J. Bellia, Jr. \& Bradford R. Clark, The Alien Tort Statute and the Law of Nations, 78 U. CHI. L. Rev. 445, 494-507 (2011); Anthony J. Bellia, Jr. \& Bradford R. Clark, The Federal Common Law of Nations, 109 Colum. L. Rev. 1, 29-31 (2009); Anthony J. Bellia, Jr. \& Bradford R. Clark, The Law of Nations as Constitutional Law, 98 VA. L. REv. 729, 758-60 (2012). 
the Judiciary Act of 1789. ${ }^{142}$ Senator Oliver Ellsworth, the Act's architect, faced conflicting demands with respect to ensuring a federal forum for British creditors. ${ }^{143}$ Article IV of the Jay Treaty required the removal of obstacles to collection of debts held by British creditors, and Ellsworth believed that Article IV needed to be effectively enforced. ${ }^{144}$ But Ellsworth also recognized that the creation of a more hospitable alternative for British creditors might not pass Congress given "strong visceral opposition to the creation of federal courts that would facilitate British creditors' debt-collection efforts." 145 Ellsworth accordingly included a five hundred dollar amount-incontroversy requirement in the circuit courts' alienage and diversity jurisdiction, a dollar amount that barred "the great majority of British claims from the new federal courts." 146 "Because of its impact upon the British debt cases," Casto argues, "the five-hundred dollar limitation was the most significant compromise in Ellsworth's bill."147

One way that concerns about the claims of British creditors may have influenced the scope of section 25 review directly is through the two thousand dollar amount-in-controversy requirement in section 22 that appears to have been incorporated into section 25 through its "in the same manner and under the same regulations" language. And the way in which this happened is linked to concerns about the cost of Supreme Court appellate review. In a section-by-section markup of the proposed judiciary bill accompanying a July 1789 letter from Virginia's Edmund Pendleton to James Madison, Pendleton drew an explicit connection between the costs of appeal and an amount-incontroversy requirement for section 25 . In his comments on section 25, Pendleton wrote: " $[\mathrm{S}]$ hould there not be some limitation of the sum for will not the Clause embrace the Case of every British Creditor? And is it intended that they may drag every [debtor] for the most triffling sum first thro' the State Courts \& then by Appeal to the seat of Congress." 148

142 See William R. Casto, The Supreme Court in the Early Republic: The Chief JusTiceships OF JoHn Jay and Oliver Ellsworth 51-52 (1995); Wythe Holt, "To Establish Justice": Politics, the Judiciary Act of 1789, and the Invention of the Federal Courts, 1989 DukE L.J. 1421.

143 On Ellsworth as "father" of the Judiciary Act, see Letter of William Loughton Smith to Edward Rutledge (July 5, 1789) reprinted in 69 S.C. Hist. Mag. 1, 10 (1968) (describing Ellsworth as the "father" of the Act, who "defends every clause valiantly"); MACLAY's JourNAL (Edgar Maclay ed., 1890) ("This vile bill is a child of [Ellsworth's], and he defends it with the care of a parent, even with wrath and anger."); see also William R. CASTO, Oliver Ellsworth and the Creation of the Federal Republic 60 (1997) ("In addition to being the formal chairman of the Committee, his fellow senators viewed [Ellsworth] as the 'leading projector' of the judiciary measure. It was Ellsworth's bill.").

144 CASTO, supra note 142, at 46.

$145 I d$. at 52.

$146 I d$. at 47.

147 Id.

148 Letter from Edmund Pendleton to James Madison (July 3, 1789) reprinted in 4 DHSC, supra note 48 , at $444,448$. 
Although William Casto has argued persuasively that the five hundred dollar amount-in-controversy limitation for circuit court original jurisdiction was "the most significant compromise in Ellsworth's bill," he does not extend his insights into the centrality of concerns about British debtors to consideration of the higher amount in controversy governing the Supreme Court's appellate jurisdiction. Casto does not address Pendleton's perspective, arguing that appellate review of state court decisions was available in theory regardless of the amount in controversy but would not be pursued in practice because of expense. ${ }^{149}$ Yet the "costs of appeal" argument cuts both ways, and the threat of an appeal by a party with superior resources was a concern at the time, as Pendleton's comment reveals. Nor was Pendleton's worry about British creditors dragging debtors through the courts for trifling sums baseless. True, the limitation of section 25 review to legal issues of federal law (via the writ of error) would have prevented many appeals from having legal efficacy - as the debtors largely relied on unreviewable jury determinations that the debtors had sufficiently paid and that the creditors were not entitled to interest. ${ }^{150}$ But the costs of litigation were high, and the threat of an appeal and costly legal process would have strengthened the creditors, as Pendleton recognized. If section 25 had not incorporated section 22's amount-in-controversy requirement, then there would have been a way back into federal court for British creditors with low dollar value debts, and this option would have affected settlement values even if rarely exercised because of expense.

The importance of Pendleton's perspective on the desirability of an amount-in-controversy requirement should not be underestimated. During the same session that Congress considered the first Judiciary Act, it also considered the first set of constitutional amendments. And one of those amendments dealt with a proposed amount-in-controversy requirement for Supreme Court appellate review. The need to have an amount-in-controversy requirement for Supreme Court appellate review had been a lingering concern in Virginia dating back to the ratification debates. During those debates, Edmund Randolph had identified "the two most material defects" of the Supreme Court's appellate jurisdiction under Article III as the Court's "appellate jurisdiction as to fact, and in trivial sums."151 Notably, Randolph's linkage of these two issues together is mirrored in a two-part constitutional amendment proposed by Madison during the first Congress.

As proposed by Madison, the amendment providing an amount-in-controversy limitation for Supreme Court appellate review was written to be

149 See CASTO, supra note 142, at 47 ("In theory, Supreme Court appellate review was available to correct errors in the tremendous number of British claims relegated to the mercy of state judiciaries. In practice, however, an appeal all the way to the Supreme Court would have been prohibitively expensive in comparison to the size of the claim.").

150 See F. Thornton Miller, Juries and Judges Versus the Law: Virginia's Provincial Legal Perspective, 1783-1828, at 40-43 (1994).

151 See 10 The Documentary History of the Ratification of the Constitution: VirgINIA, No. 3, at 1455 (John P. Kaminski \& Gaspare J. Saladino, eds., 2009). 
inserted in Article III, section two, at the end of the second clause-immediately after the provision authorizing congressional "regulations" of the Supreme Court's appellate jurisdiction. The amendment provided that "no appeal to such court shall be allowed where the value in controversy shall not amount to dollars: nor shall any fact triable by jury, according to the course of common law, be otherwise re-examinable than may consist with the principles of common law."152

The second part of this proposed amendment made it into the provision that became the Seventh Amendment, and is now known as the Re-examination Clause. But as Madison explained in a letter to Edmund Pendleton written ten days before Congress finally adopted the Judiciary Act, the constitutional amount-in-controversy amendment failed in the Senate. ${ }^{153}$ One of the reasons the proposed amendment failed was a concern that it could exclude Supreme Court consideration of important federal questions that arose in cases under the amount-in-controversy requirement. ${ }^{154}$ One might view this reason for the failure of a constitutional amount-in-controversy requirement as a reason for rejecting a civil-only reading of section 25 . After all, important federal questions had the potential to arise in criminal cases as much as civil cases. But this neglects the most radical significance of the amount-in-controversy requirement, which is that it presupposed a civilonly understanding of the Supreme Court's appellate jurisdiction.

Understanding the failed constitutional amount-in-controversy requirement is important also because the statutory amount-in-controversy requirement for Supreme Court appellate review in section 22 may have been a consolation prize for those who supported the constitutional amendment. The original Senate bill included a two thousand dollar amount-in-controversy requirement for Supreme Court appellate review of circuit court decisions, but only in cases that had come up from the district court to the circuit courts. The original version of the Act did not include an across-the-board amount-in-controversy requirement until a House amendment extended it to Supreme Court appellate review of all federal circuit court decisions. ${ }^{155}$

This amendment also explains what otherwise is puzzling about Pendleton's July 1789 letter to Madison proposing an amount-in-controversy requirement for section 25. If section 25 incorporated section 22's amountin-controversy requirement, as argued above, then why would Pendleton

152 Letter of James Madison to Edmund Randolph (May 31, 1789), reprinted in 5 THE Writings of James Madison: 1787-1790, at 372, 379 (Gaillard Hunt, ed. 1904).

153 Letter of James Madison to Edmund Pendleton (Sept. 14, 1789) reprinted in 4 DHSC, supra note 48, at 511.

154 Letter of James Madison to Edmund Pendleton (Sept. 23, 1789), reprinted in 4 DHSC, supra note 48, at 517 (explaining that "[i]t will be impossible I find to prevail on the Senate to concur in the limitation on the value of appeals to the Supreme Court, which they say is unnecessary, and might be embarrassing in questions of national or constitutional importance, tho' of small pecuniary amount").

155 See 4 DHSC, supra note 48, at 79. ("The House made one very important amendment [to Section 22], extending the $\$ 2,000$ limitation on appeals to the Supreme Court to all cases instead of just those originating in the district court."). 
have suggested the addition of such a requirement? The answer is that the version reviewed by Pendleton, which was the original Senate bill, had not yet included an across-the-board amount-in-controversy requirement for Supreme Court appellate review in section 22. And section 25 was always parasitic on section 22. Only after this two thousand dollar amount-in-controversy requirement applied to all circuit court cases in which section 22 provided for Supreme Court appellate review might this requirement have been understood as a regulation of jurisdiction incorporated by section 25's "in the same manner and under the same regulations" language.

If section 25 incorporated section 22's amount-in-controversy requirement, then the constitutional amendment proposed by Madison was not a total failure. For the amount-in-controversy requirement that the Senate rejected as a constitutional matter would have made it into the Judiciary Act of 1789 as a statutory matter. This makes the civil-only presupposition of the Supreme Court's appellate jurisdiction under Article III that was built into the proposed constitutional amendment less surprising. After all, as we have seen, the Act itself explicitly confined the Supreme Court's appellate review of cases from the federal courts to civil cases only.

Having reviewed the most important aspects of Congress's consideration of the Judiciary Act for what it might reveal of a civil/criminal distinction in section 25, the fairest conclusion seems to be that broader considerations beyond the text of the Judiciary Act of 1789 are not decisive one way or other regarding the civil-only interpretation of section 25. But the evidence for a civil-only interpretation is much stronger and the evidence for a combined civil and criminal reach is much weaker than commonly thought. Although it is tempting to argue against the more limited, civil-only understanding of section 25 by appealing to a broad purpose to protect the supremacy of federal law, that kind of argument risks being overly simplistic and somewhat anachronistic. In establishing the federal judiciary in such a way as to ensure the supremacy of federal law, Congress needed to compromise and consider not only other interests, but also other ways of protecting federal supremacy apart from direct appellate review. The bitter disputes over the relationship between state and federal courts in Martin v. Hunter's Lessee and over expansive federal legislative power in cases like McCulloch v. Maryland and Cohens $v$. Virginia are such a prominent part of the story of section 25 that it is easy to forget that the concerns behind section 25 were different in 1789 . While some opponents of the Judiciary Act included section 25 in their opposition, it was a largely uncontroversial provision. Congress's concern was focused on particular federal interests, with special attention devoted to conflicting demands regarding the claims of British creditors. Preservation of federal interests through federal court adjudication was always in recognized tension with other interests, and Congress imposed important limitations on the reach of Supreme Court appellate review to accommodate these conflicting interests. 


\section{B. The Objection that Civil-only Section 25 Is Too Novel to Be Right}

A second objection flows from the understandable impulse to think that it just cannot be right that we are only now finding out about the correct interpretation of section 25. If the arguments for civil-only section 25 are so good, why were they not more apparent to interpreters around the time of Cohens v. Virginia? And why have they not only been ignored but forgotten and buried after Cohens?

Before answering these questions, it is important to be clear about the limits of the objection. The civil-only interpretation is novel in the sense that it has not occurred to anyone for almost two centuries to examine whether it might be right. But the civil-only interpretation is not completely new; the arguments set forth in Part I are rooted in arguments made at the time of Cohens and earlier. The "novelty" objection, therefore, is about novelty in the present, which in turn translates into questions about why the civil-only interpretation of section 25 was not more carefully considered around the time of Cohens, and why it was completely forgotten once the furor over Cohens died down.

The best way to address these questions is probably to consider them from the perspective of the important actors around the time of Cohens $v$. Virginia. Let us begin by considering the silence of Virginia's lawyers. They were seemingly best positioned in Cohens to make the argument that the Supreme Court lacked statutory jurisdiction to engage in appellate review via writ of error in state court criminal prosecutions. These lawyers had been specifically instructed to argue that the Supreme Court lacked jurisdiction, and the jurisdictional issue only; if the Court were to decide that it possessed jurisdiction (as it did), these lawyers were to go home (as they did) rather than argue the merits. ${ }^{156}$ One might think that this charge would have made the lawyers especially attentive to arguments for no statutory jurisdiction. But Virginia's opposition to Supreme Court review was constitutionally based; to argue that Congress had simply failed to provide for appellate jurisdiction in a category of cases for which Article III authorized jurisdiction would have been in tension with Virginia's position on the scope of Article III. ${ }^{157}$

\section{See LucE, supra note 10, at 121.}

157 Two other reasons that Virginia's lawyers may not have raised the statutory jurisdiction arguments analyzed in this Article can be seen by considering how those arguments would have related to other arguments advanced by Virginia. First, the argument about the limited ordinary meaning of "suit" set forth above would have been in tension with Virginia's argument that the Eleventh Amendment barred Supreme Court appellate review in Cohens - that the writ of error was a "suit" prosecuted against the state in violation of the Eleventh Amendment. Second, a bad statutory jurisdiction argument may have crowded out the good ones. In order to advance their merits argument while honoring the instruction only to argue jurisdiction, Virginia's lawyers reframed their merits argument in jurisdictional terms. They argued (unconvincingly) that section 25 did not authorize jurisdiction because its authorization was limited to claims denying rights protected by federal law, but the federal statute at issue did not actually authorize the selling of lottery tickets (for which the Cohens were prosecuted). 
A similar dynamic may have been at work at the Supreme Court, albeit in reverse. Dismissal for lack of statutory jurisdiction in Cohens would have been an unsatisfactory half measure even if the Court could have secured its jurisdiction under Article III. Particularly in light of the absence of any party raising the arguments about statutory jurisdiction set forth above, there was no reason for the Court to dig too deeply into the issue. ${ }^{158}$ Were the Court to have concluded that it lacked statutory jurisdiction over state criminal prosecutions, it is doubtful that Congress would have extended jurisdiction any time soon even if Article III permitted it. And this was an unattractive prospect, for the Court did not simply need jurisdiction, but jurisdiction that it could exercise immediately. ${ }^{159}$

This talk about the Supreme Court as a single entity, though, is not entirely satisfying even if accurate. For the Court is a collectivity-a "they, not an it." 160 And the member of the collectivity best positioned to appreciate the problem with statutory jurisdiction, Justice William Johnson, has left us only with confounding silence on the civil-only understanding of section 25 that he had advanced just five years earlier. Under the leadership of Chief Justice John Marshall, the Supreme Court spoke most of the time with just one voice-Marshall's. Justice Johnson was an exception, the only Marshall Court justice who wrote separately in constitutional cases to any significant degree. ${ }^{161}$ Given Johnson's unusual willingness (for the Marshall Court) to write separately, why did he not write separately in Cohens to explain how his views on Supreme Court jurisdiction over state-court criminal prosecutions had seemingly changed from just five years earlier? This remains a mystery. It is noteworthy, though, that Cohens came in the middle of a four-year period beginning in 1819 in which Justice Johnson largely stopped writing separate opinions altogether. Justice Johnson's biographer suggests that Johnson's

158 This is not to say that the Court would have been disabled from reaching the issue. The Supreme Court's 1805 determination that it lacked jurisdiction to review criminal prosecutions from the D.C. Circuit Court came after sua sponte questioning from Chief Justice Marshall. See United States v. More, 7 U.S. (1 Cranch) 169 (1805) ("The Chief Justice suggested a doubt about whether the appellate jurisdiction of this court extends to criminal cases." (emphasis omitted)).

159 The idea that high stakes in a legal dispute may result in blindness to lower stakes dispositions may be another still-valuable lesson illustrated by this Article's consideration of civil-only Section 25. Maybe the low practical stakes of a civil-only Section 25 today will render scholars more willing to consider its legal correctness notwithstanding the importance of the interpretation in either strengthening or weakening existing theories about the Judiciary Act of 1789 and Article III.

160 See, e.g., Adrian Vermeule, The Judiciary Is a They, Not an It: Interpretive Theory and the Fallacy of Division, $14 \mathrm{~J}$. Cont. Legal Issues 549 (2005).

161 See Donald G. Morgan, Justice William Johnson: The First Dissenter, The Career and Constitutional Philosophy of a Jeffersonian Judge 176 (1954) ("[W]ith the sole exception of William Johnson, no member of the Marshall Court during the years prior to 1823 spoke out in separate opinions, whether concurring or dissenting, in more than eight cases."); id. at 179 (noting that Johnson "contributed exactly half of the concurring and half the dissenting opinions delivered by all the judges between his advent and the close of the 1822 term"). 
dissatisfaction with his job and his work on a book-length biography of Nathaniel Greene may explain some of his silence. ${ }^{162}$ Whatever the causes may have been, correspondence with Jefferson later shook Johnson out of his silent streak, and he was back writing separately in important cases starting in 1823. ${ }^{163}$ In none of those later opinions, however, does Johnson explain his seeming about-face on statutory jurisdiction for Supreme Court appellate review of state criminal prosecutions.

Another possibility is that nobody directly involved in Cohens took time to read section 25 carefully and explore the relationship of its language with other provisions of the Act. After all, it was not until 1823 in Beul that the Supreme Court confronted the question of section 25's incorporation of section 22's amount-in-controversy requirement. Alexander Dallas's 1814 letter to Congress shows that the incorporation reading was not idiosyncratic to Charles Hammond. Yet nobody appears to have made this argument directly to the Court until William Wirt advanced it in Beul. It is intriguing to speculate whether Wirt, who represented the Cohen brothers in Cohens, might have picked up this incorporation argument from Hammond's post-Cohens newspaper essays. (Indeed, Wirt might have been one of the likely few people to have actually read through all of those essays.)

Widespread neglect of arguments in favor of civil-only section 25 is much easier to explain after Cohens. Given the Court's decision in that case with respect to constitutional jurisdiction and its unproblematic acceptance of statutory jurisdiction, any post-Cohens argument that section 25 did not extend to criminal cases would not have been given much of a chance by experienced counsel. Perhaps this is why Georgia, which later argued for a lack of statutory jurisdiction under section 25 on other grounds in Worcester $v$. Georgia, ${ }^{164}$ did not advance an argument along these lines.

If one can understand why the civil-only understanding of section 25 held little allure in the world of practice, what explains the neglect of scholars since then? One explanation is disciplinary. Legal historians tend not to frame their inquiries in a way that would yield the narrowly legal argument that section 25 review did not, as a matter of law, authorize Supreme Court appellate review of state criminal prosecutions. Although academic lawyers are more open to considering a hard-edged legal claim like this, many lack the historical background to recognize the strength of the legal arguments insofar as they depend on understanding the text of section 25 in historical context. But specialists in federal jurisdiction who have extensively studied the original meaning of Article III and the Judiciary Act of 1789 are familiar enough with the historical context to evaluate this Article's arguments about civil-only section 25 . What about them?

The best explanation for the existing consensus probably has Cohens itself at bottom. Once one accepts Cohens's interpretation of Article III to encompass Supreme Court appellate review of state criminal prosecutions

162 See id. at 180.

163 See id. at 168-89.

16431 U.S. (1 Pet.) 515 (1832). 
involving federal questions, it is hard to imagine that Congress did not provide for statutory jurisdiction over such cases. Because one cannot fathom why Congress would have left such a gap between constitutionally authorized and statutorily provided jurisdiction, scholars have never before set out to examine whether Congress did so. One can see this mindset at work, for example, in Felix Frankfurter's and James Landis's The Business of the Supreme Court-a book at the headwaters of legal scholarship on federal jurisdiction for the past several decades. Frankfurter and Landis describe the Judiciary Act of 1789 as providing the Supreme Court with statutory "appellate jurisdiction over all classes of cases which constitutionally could be reviewed." 165

Nor is civil-only section 25 the sort of statutory interpretation that one is likely to casually alight upon. The arguments in support of this interpretation are well grounded in statutory text, but that text is remarkably dense. Moreover, those who do inspect the full original text of section 25 now might not fully understand the import of its language without considering it both in its larger statutory context and in the wider legal universe of the late eighteenth century. One needs a guide from the time like Charles Hammond, but Hammond is now obscure and one can only find his statutory arguments by reading through the tenth of his eleven essays on Cohens.

Many scholars of federal jurisdiction may never have even read section 25 all the way through, much less considered how its parts interact with other sections of the Judiciary Act of 1789. The leading federal courts casebook devotes almost half a page to setting forth the text of section 25 in its early summary of jurisdiction provided under the Act, and even that version is highly abbreviated, leaving out most of the statutory language discussed above (viz. "any suit," "in the same manner and under the same regulations," and "may ... proceed to a final execution"). ${ }^{166}$ Although the casebook's later discussion of Supreme Court appellate review of state court decisions does include an annotated version of the entire statutory text, the annotations do not indicate when all of the different pieces of statutory text discussed in Part I were amended into their present form. ${ }^{167}$ And in fact, there was no single amendment that eliminated all these different pieces, which rather melted away over time in a series of amendments, none of which were intended to expand a civil-only reading to include criminal prosecutions.

165 Felix Frankfurter \& James M. Landis, The Business of the Supreme Court: A Study in the Federal Judicial System 13 (1927) (emphasis added). These distinguished scholars did not even qualify this claim by noting the absence of Supreme Court appellate jurisdiction over federal court criminal prosecutions. And yet the linkage between statutory and constitutional jurisdiction is still credited by scholars today who recognize that limitation. See Crowe, supra note 121, at $39 \&$ n.12 (citing Frankfurter and Landis for the proposition that the Judiciary Act granted "appellate jurisdiction over all classes of casesboth from lower federal courts and state courts-that [constitutionally] could be reviewed").

166 See Richard H. Fallon, Jr. et al., Hart \& Wechsler's the Federal Courts and the Federal System 25 (6th ed. 2009).

167 Id. at 431-32. 
In the end, the novelty associated with resurrecting the dead and buried civil-only interpretation of section 25 is reason to proceed with caution. But the arguments for and against the interpretation can stand on their legal merits regardless of whether they are familiar or forgotten.

\section{The Objection that Civil-only Section 25 Is Unconstitutional}

In addition to the objections from statutory purpose and novelty, another type of objection is that Section 25 would be unconstitutional if limited to authorizing Supreme Court appellate review of state cases denying federal-law-based rights in civil cases only. This objection can be formulated in constitutional avoidance terms: Because leaving the Supreme Court without authority to engage in appellate review of state criminal cases denying federal-law-based rights would be unconstitutional, an interpretation that yields such an outcome should be avoided if reasonably possible. ${ }^{168}$

An initial question facing this objection is whether a reading of section 25 to include appellate review of state criminal prosecutions is reasonably possible. This is a harder question now than it would have appeared before one had considered the arguments set forth in Part I. In order to conclude that it is reasonably possible to understand section 25 as including review of state criminal prosecutions, an interpreter would not only need to interpret "any suit" to encompass a state criminal prosecution, but also would have to exclude the amount-in-controversy requirement from incorporation and to ignore the civil-only implications of the provision authorizing award of execution. Each one of these interpretive moves is questionable on its own; putting them all together is unlikely to be right. Nevertheless, it is difficult to conclude that the operative understanding of section 25 for decade upon decade to include criminal prosecutions is not a reasonably possible interpretation of the language.

The next question is how hard to strain to avoid the potential constitutional problem. This, in turn, depends on whether there is any constitutional problem to avoid. That is, the force of any constitutional avoidance objection to a civil-only interpretation of section 25 obviously depends on the force of the underlying argument for unconstitutionality. If arguments for mandatory Supreme Court appellate jurisdiction over state criminal prosecutions resolving questions of federal law are unsuccessful, then this unconstitutionality objection to civil-only section 25 dissolves.

This Article about section 25 is not the place for a full airing of the arguments for and against the various mandatory theories that would render section 25 unconstitutional. The extent of congressional control over federal court jurisdiction is one of the most extensively examined topics in the scholarly literature of federal courts; well known and well developed arguments

168 See, e.g., Nat'l Fed'n of Indep. Bus. v. Sebelius, 132 S. Ct. 2566, 2593 (2012) (opinion of Roberts, C.J.) ("[I]f a statute has two possible meanings, one of which violates the Constitution, courts should adopt the meaning that does not do so."). 
have been presented with thoroughness and care by many other scholars. ${ }^{169}$ Rather than rehearse or reshuffle these, I will simply report my own present conclusion that the various mandatory theories under which civil-only section 25 would be unconstitutional are unpersuasive, largely for textual reasons expounded by Professor John Harrison, ${ }^{170}$ historical reasons elaborated by Professor Daniel Meltzer, ${ }^{171}$ and the original meaning of "all cases" most recently set forth by Judge William Fletcher ${ }^{172}$ (though much earlier set forth by Charles Hammond in his commentaries on Cohens). ${ }^{173}$

Rather than allow a constitutional avoidance reason to distort what otherwise seems to be the correct, civil-only interpretation of section 25 , it is more fruitful to consider how that interpretation fits into the existing debate over congressional control of federal jurisdiction. Arguments about the existence, size, and reasons for various gaps between constitutionally authorized and statutorily provided jurisdiction in the Judiciary Act of 1789 are a staple of arguments among various interpreters of Article III. Some influential federal courts scholars have argued for a mandatory understanding of "arising under" jurisdiction, such that Congress is obligated to provide federal court jurisdiction in some form over every case that arises under federal law. And other influential scholars defending the old orthodoxy of virtually plenary congressional control over federal jurisdiction have argued in response that these mandatory theories are inconsistent with the Judiciary Act of 1789, which provided substantially less federal jurisdiction than these theorists contend Congress was constitutionally obliged to provide.

Civil-only section 25 provides new arguments for the old orthodoxy in this ongoing scholarly debate. To see precisely how it does so, consider Akhil Amar's position in The Two-Tiered Structure of the Judiciary Act of $1789 .{ }^{174}$ In that article, Amar defends his mandatory two-tier interpretation of Article III (an interpretation of Article III that he developed from earlier arguments by Joseph Story). Under Amar's interpretation of Article III, there are three categories to which the federal judicial power extends for which Congress

169 It is as easy as it is pointless to multiply authorities here. Cf. Orin S. Kerr, A Theory of Law, 16 GREen BAG 2D 111 (2012). The first footnote of an article on this very topic from almost twenty years ago, for example, cited thirty articles (with authors from Amar to Young) for the proposition that "[t]he extent of Congress's authority to control the jurisdiction of the federal courts has been the subject of unending academic debate." Julian Velasco, Congressional Control over Federal Court Jurisdiction: A Defense of the Traditional View, 46 CAтн. U. L. Rev. 671, 671-72 n.1 (1996). For a relatively recent overview of the state of the debate, see James E. Pfander, Federal Supremacy, State Court Inferiority, and the Constitutionality of Jurisdiction-Stripping Legislation, 101 Nw. U. L. Rev. 191 (2007).

170 Harrison, supra note 8.

171 Meltzer, supra note 21.

172 William A. Fletcher, Congressional Power over the Jurisdiction of Federal Courts: The Meaning of the Word "All" in Article III, 59 Duke L.J. 929 (2010) (explaining that the function of "all cases" in Article III's description of the extent of federal judicial power is to enable discretionary vesting of exclusive jurisdiction in the federal courts).

173 See Charles Hammond, No. III, reprinted in Review of the Opinion, supra note 15. 174 Amar, supra note 5. 
must provide for federal jurisdiction, and six categories for which Congress may provide for federal jurisdiction. Cases arising under federal law are in the mandatory tier (together with admiralty cases and cases affecting ambassadors and public consuls). Against those scholarly critics who see inconsistency between this interpretation of Article III and the Judiciary Act of 1789, Amar argues that "[i]n its general structure and in a great many of its specific provisions, the Act validates the main tenets of Story's two-tier thesis, as revised and elaborated [by Amar] in 1985." 175 With respect to section 25 in particular, Amar argues that "the Supreme Court was given plenary appellate review, under the famous section 25 , over all state court decisions which defeated rights set up by the appellant under the Constitution, laws or treaties of the United States." 176 Contrasting the Judiciary Act's treatment of "arising under" cases with diversity cases later in the article, Amar writes that "when Congress turned to federal question appeals from state courts to the U.S. Supreme Court under section 25, it chose a truly de minimis amount-in-dispute requirement: zero." 177 But because section 25 did not provide for appellate review of state criminal prosecutions, and further restricted review of judgments in civil suits through a two thousand dollar amount-in-controversy requirement on top of that, Amar's claims about section 25 are mistaken. And his claim of fundamental consistency between the Judiciary Act of 1789 and a mandatory theory of Article III that encompasses "arising under" jurisdiction is incorrect.

Although Amar's claims about the Judiciary Act of 1789 and Article III have attracted powerful criticisms from scholars such as Daniel Meltzer and John Harrison, those scholars also appear to have accepted the received understanding of section 25's reach to encompass criminal cases and to include no amount-in-controversy requirement. ${ }^{178}$ For example, Meltzer discusses the gap between section 25 and Article III resulting from section 25's limitation to denials of rights protected by federal law, but he does not address either the civil-only reading of section 25 or the incorporation of an amount-in-controversy requirement from elsewhere in the Act. And Harrison explicitly asserts that "Section 25 of the Judiciary Act of 1789 . . provided for federal appellate jurisdiction over state criminal prosecutions in some circumstances." 179

In the end, the ultimate validity of various mandatory theories of Article III should probably turn on considerations other than correspondence with the Judiciary Act of 1789. This is so even if one shares Chief Justice Marshall's view in Cohens that the actions of the first Congress provide a contem-

\section{Id. at 1516.}

176 Id. at 1519 (emphases added); see also id. at 1529-30 (asserting that, in section 25, "Congress sought to obey the obligation to vest plenary 'arising under' jurisdiction in federal courts").

177 Id. at 1520.

178 See Harrison, supra note 8; Meltzer, supra note 21.

179 Harrison, supra note 8, at 234. 
poraneous exposition of the Constitution that is of great authority. ${ }^{180}$ That authority should not defeat a clean argument from constitutional text, after all, any more than would a mistaken interpretation in the Federalist Papers. And Congress could have erred, or could have been disorganized or confused. ${ }^{181}$ This has been known to happen. In any event, the objection from unconstitutionality usefully reveals how interpretations of section 25 plug directly into ongoing scholarly debates-debates thus far conducted without any consideration of the arguments tending to establish that section 25 did not authorize Supreme Court appellate review of state criminal prosecutions.

\section{Beyond Civil-Only Section 25}

The responses to various objections considered in the preceding Part have already begun to reveal the present-day import of this Article's examination of civil-only section 25. This Part expands beyond section 25 and the Judiciary Act of 1789 to consider broader implications of the surprising rediscovery of civil-only section 25 . At a general level, the possibility-indeed, the strong likelihood-that the first Congress did not authorize Supreme Court direct appellate review of state criminal prosecutions resulting in the rejection of a federal-law-based right, immunity, or defense matters now precisely because it fits so uneasily with much of what we think we know about the establishment and development of federal jurisdiction. While this Article's claims about civil-only section 25 can be joined seamlessly into the ongoing scholarly debates about congressional control over federal jurisdiction, the more interesting and potentially wide-ranging import of the arguments for civilonly section 25 is for debates that have yet to happen or are in areas of scholarly concern distinct from seemingly narrow and technical legal questions about the interpretation of this single statutory provision.

Writing as Publius, Alexander Hamilton observed in Federalist No. 82 that

[t] he erection of a new government, whatever care or wisdom may distinguish the work, cannot fail to originate questions of intricacy and nicety; and these may, in a particular manner, be expected to flow from the establishment of a constitution founded upon the total or partial incorporation of a number of distinct sovereignties. ${ }^{182}$

Hamilton was talking there about Article III. And it is no coincidence. The judiciary was particularly prone to generating such "questions of intricacy and nicety" because the Constitution did not completely constitute the fed-

180 See Cohens v. Virginia, 19 U.S. (6 Wheat.) 263, 420 (1821).

181 See, e.g., Laurence Claus, The One Court that Congress Cannot Take Away: Singularity, Supremacy, and Article III, 96 GEO. L.J. 59, 104 (2007) ("The history of the [Judiciary] Act's adoption confirms what the Act's chaotic structure suggests: that the Judiciary Act might better be described as exhibit A for proving the first Congress's discord and failure to read Article III coherently.").

182 The Federalist No. 82, at 282 (Alexander Hamilton) (2005). 
eral judiciary, but left significant details of the structure to be devised by Congress. ${ }^{183}$

Congress began this process in the Judiciary Act of 1789. But it took a course of over three decades before something as basic as "arising under" jurisdiction was judicially liquidated into the form that it has taken to this day. ${ }^{184}$ The need for this course of adjustment and clarification was understood at the beginning. Hamilton's observation in Federalist No. 82 identified a category of questions raised but not resolved by the Constitution. For Hamilton did not assert that the Constitution itself would supply answers to all the "questions of intricacy and nicety" that would arise in working out the relationship between federal and state courts. He asserted, instead, that it would take time and future developments to determine the answers: "[it] is time only that can mature and perfect so compound a system, can liquidate the meaning of all the parts, and can adjust them to each other in a harmonious and consistent whole."185 In stating this, Hamilton echoed James Madison's earlier observation, also written as Publius, that "[a]ll new laws, though penned with the greatest technical skill, and passed on the fullest and most mature deliberation, are considered as more or less obscure and equivocal, until their meaning be liquidated and ascertained by a series of particular discussions and adjudications." 186

Cohens $v$. Virginia was a crucial decision in this process of constitutional liquidation. This Article is not the occasion for a full examination of the correctness of the Court's constitutional reasoning. But the significance of that reasoning is unquestionable. Even if the ultimate determination of constitutional jurisdiction in Cohens was correct under Article III, Chief Justice Marshall's opinion for the Court resolved a number of tensions in Article III that could have been resolved other ways even while reaching the same outcome. These alternative resolutions, in turn, could have led to a very differ-

183 As one scholar recently put it,

[e]ffectively functioning as 'a compromise by postponement,' the defining feature of Article III is the way in which the framers of the Constitution essentially placed the institutional structure of the judiciary in the hands of Congress, thereby making it inevitable that debate about the structure of the federal judiciary would reemerge in the course of ordinary politics in the future.

Crowe, supra note 121, at 27 (citations omitted).

184 The Marshall Court's enduring opinion on "arising under" jurisdiction is Osborn $v$. Bank of the United States, 22 U.S. (9 Wheat.) 738 (1824), which itself was shaped in important respects by Cohens v. Virginia. See generally Charles F. Hobson, The Great Chief Justice: John Marshall and the Rule of Law 124 (1996) (describing Cohens and Osborn as opinions that "elicited the chief justice's most elaborate inquiries into the constitutional foundations and extent of federal judicial power").

185 The Federalist No. 82, supra note 182, at 282. For an extensive recent discussion of constitutional liquidation, see Stephen E. Sachs, The "Unwritten Constitution" and Unwritten Law, 2013 U. ILl. L. Rev. 1797. Another in-depth treatment of the practice appears in Caleb Nelson, Originalism and Interpretive Conventions, 70 U. CHI. L. REv. 519 (2003).

186 The Federalist No. 37, at 122 (James Madison) (2005). It is perhaps no coincidence that Madison was also speaking in this paragraph about jurisdiction. 
ent operative understanding of Article III than is now embedded in jurisdictional doctrine. For example, Cohens decided that Article III's distribution of state-party cases to the Supreme Court's original jurisdiction did not apply to cases arising under federal law. ${ }^{187}$ That interpretation is probably contrary to the original legal meaning of the Distribution Clause. ${ }^{188}$ Without this aspect of Cohens, original jurisdiction suits against states based on claims arising under federal law might have been more prominent. Or, to pick another example, Cohens determined that there were some cases "arising under" federal law that could not be within the original jurisdiction of a federal court because they could only originate in a state court. ${ }^{189}$ That interpretation, too, may be contrary to the original legal meaning of Article III. ${ }^{190}$ If this part of Cohens had come out differently, pretrial removal of criminal prosecutions raising federal questions may have been a more widely used tool.

The suggestion that there was no statutory jurisdiction in Cohens indicates a potentially significant divergence between the clear constitutional vision animating the Chief Justice's opinion and competing constitutional understandings in the first Congress that ended up partially embedded in various ways in the Judiciary Act of 1789. And recognizing that a holding of no statutory jurisdiction provides a path not taken makes it easier to understand that Cohens did not have to turn out as it did. Although scholars have been able to piece together the original legal meaning of various portions of Article III

187 Cohens v. Virginia, 19 U.S. (6 Wheat.) 264, 393-94 (1821) ("When . . the constitution declares the jurisdiction, in cases where a State shall be a party, to be original, and in all cases arising under the constitution or a law, to be appellate-the conclusion seems irresistible, that its framers designed to include in the first class those cases in which jurisdiction is given, because a State is a party, and to include in the second, those in which jurisdiction is given, because the case arises under the constitution or a law."); $i d$. at 398-99 (" $[\mathrm{T}]$ he original jurisdiction of the Supreme Court, in cases where a State is a party, refers to those cases in which, according to the grant of power made in the preceding clause, jurisdiction might be exercised in consequence of the character of the party, and an original suit might be instituted in any of the federal Courts; not to those cases in which an original suit might not be instituted in a federal court.").

188 See Pfander, supra note 18.

189 Cohens, 19 U.S. (6 Wheat.) at 394 ("That the constitution or a law of the United States, is involved in a case, and makes a part of it, may appear in the progress of a cause, in which the Courts of the Union, but for that circumstance, would have no jurisdiction, and which of consequence could not originate in the Supreme Court. In such a case, the jurisdiction can be exercised only in its appellate form. To deny its exercise in this form is to deny its existence, and would be to construe a clause, dividing the power of the Supreme Court, in such manner, as in a considerable degree to defeat the power itself. All must perceive, that this construction can be justified only where it is absolutely necessary. We do not think the article under consideration presents that necessity.").

190 As explained above, William Fletcher and Charles Hammond have argued that the original meaning of "all cases" in Article III's description of the extent of federal judicial power is to enable discretionary vesting of exclusive jurisdiction in the federal courts. See generally Hammond, supra note 173; Fletcher, supra note 172. The assertion that there can be no appellate-only jurisdiction is a corollary of this claim. Federal jurisdiction that is appellate-only cannot be exclusive. 
notwithstanding tension between their findings and various aspects of the Court's opinion in Cohens, the rediscovery of civil-only section 25 should prompt the question: What else might we currently be missing because of the difficulty imagining a federal jurisdictional structure without Cohens-that is, all of Cohens - as a foundation?

To appreciate the nature of this problem, it is helpful to shift from the idea of constitutional liquidation to the concept of constitutional construction. ${ }^{191}$ This shift enables us to better conceptualize the difficulty facing those interested in discerning the original legal meaning of Article III while living in the world that Cohens made. It is akin to the difficulty in discerning the original design in smudged architectural drawings after someone else has already constructed a beautiful and functional building from those drawings. After this construction has stood the test of time, interpreters of the original drawings cannot help but have their understanding of the smudged drawings formed to some degree by what was actually built. Such is the influence of the enduring Marshallian construction of Article III in Cohens v. Virginia.

This influence can be counteracted by careful attention to pre-construction sources. And it also helps to have a knowledgeable guide. That is where Charles Hammond comes in. Hammond's neglected arguments about civilonly section 25 were in just one of his eleven essays on Cohens $v$. Virginia; the other ten were about the Constitution. By recovering, developing, and defending Hammond's claims about section 25 of the Judiciary Act of 1789, this Article establishes Hammond's chops as an analyst of federal jurisdiction and lays the groundwork for recovering Hammond's important contributions as a constitutional lawyer and analyst of federal jurisdiction.

Having excavated, reconstructed, and augmented Charles Hammond's arguments for civil-only section 25 , it is fitting to conclude with a discussion of this Article's method and scope. This Article's core claim about the lim-

191 This concept is deployed in a variety of ways in contemporary constitutional theory, but one commonality in all such uses is to distinguish "construction" from "interpretation." Lawrence Solum uses the interpretation/construction distinction to mark the difference between determination of semantic meaning (interpretation) and determination of legal effect (construction). See Lawrence B. Solum, The Interpretation-Construction Distinction, 27 Const. Comment. 95 (2010). Thus understood, construction happens in every case that involves the application of a legal text, even when the legal meaning mirrors the semantic meaning precisely. See id. at 107-08. The earlier usage by Keith Whittington and Randy Barnett is narrower. In that usage, "interpretation" refers to the process of ascertaining textual meaning (with no distinction drawn between semantic content and legal content), while "construction" refers to the way in which insufficiently determinate text is given a legal meaning sufficiently determinate for the purpose at hand (such as judicially resolving a case). See, e.g., Randy E. Barnett, Restoring the Lost Constitution 123 (2004) ("When the abstract terms of the Constitution do not directly resolve a particular dispute, some construction (as opposed to interpretation) of constitutional meaning is need. As Whittington observes, constructions operate "where the text is so broad or so underdetermined as to be incapable of faithful but exhaustive reduction to legal rules." (quoting Keith E. Whittington, Constitutional Construction 5 (1999)). Although not rejecting the semantic/legal distinction identified by Solum, this Article uses "construction" in the narrower sense of "rendering sufficiently determinate." 
ited reach of section 25 is a legal claim supported by legal arguments. Although this Article should be of some interest to legal historians of the early Republic through Jacksonian democracy, it is primarily a work of legal analysis rather than historical investigation. It is the kind of claim that a historically oriented academic lawyer might make; legal historians, as historians, tend to adopt a broader focus for their inquiries and more tentative conclusions about specific legal claims. And while the primary audience for the Article consists of scholars of federal jurisdiction and others interested in legal analysis related to the development of federal jurisdiction, it is atypically narrow for that kind of scholarship. These features of the analysis are worth addressing explicitly.

The narrowness of this Article's frame for analysis is a feature, not a limitation. It shows how unrelenting focus on a single legal question about the reach of a single statutory provision can provoke the revisitation of aspects of the federal jurisdictional structure long taken for granted. And in the end, the biggest puzzle about section 25's application to state criminal prosecutions that this Article uncovers for legal historians is not about whether that application was authorized under section 25 as originally enacted and understood. It either was or it was not, and that's that. A bigger question for legal historians is how the more limited civil-only understanding of section 25 evident as late as 1816 in Justice Johnson's separate opinion in Martin v. Hunter's Lessee and readily available to Hammond in 1821 was overtaken so quickly and so definitively that it not only has been lost to generations looking backwards from the present, but also was not even deployed by others who wanted to limit Supreme Court jurisdiction during the 1820s and onwards. The best explanation for this effacement of section 25's apparent original meaning lies in the realm of legal history. But it is not something that legal historians have tried to explain, because they, like their scholarly confreres in the more narrowly legal field of federal courts scholarship, have not recognized the civil-only meaning of section 25 whose effacement requires explanation.

As this Article illustrates by example, the text of section 25 provides an excellent entry point into certain legal perspectives that were operative in the late eighteenth and early nineteenth centuries but are all but lost today. Careful consideration of this statutory provision unsettles the assumptions that we bring to Article III today by revealing how the first Congress addressed the relationship of the Supreme Court to state courts at a level of legal detail far more precise than the broad language of the Constitution. Yet the development of a comprehensive new understanding of either the Judiciary Act of 1789 or Article III is not an independent objective in this Article. That is a worthy ambition, but the object of this Article is different in kind: To reveal an important and heretofore unappreciated legal datum that every such theory must account for.

Like the narrowness of its substantive focus, the resolutely legal frame of this Article's analysis is also a feature, not a defect. If forced to place a modern methodological label on the interpretive approach adopted in this Arti- 
cle, the fairest label would probably be some variety of textualism. But this kind of labeling can occasionally obscure more than it reveals, and this may be one of those instances. The intent behind this Article's interpretive approach is to argue in a manner self-consciously continuous with the kinds of legal arguments that Charles Hammond made in 1821, not to demonstrate deftness in deploying or fidelity in following a particular interpretive approach. Hammond's arguments were standard lawyers' arguments, made before self-conscious interpretive -isms proliferated in the twentieth century. In both form and substance, these arguments have a remarkable durability over time. And it is this durability that allows inquisitive lawyers almost two centuries later, coming at the question with a vastly different set of suppositions about federal jurisdiction, to nevertheless recognize the strength of Hammond's legal arguments as such. Durability over time and ability to induce acceptance notwithstanding deep differences in presuppositions may be features of the arguments adduced in the predominantly textualist approach in this Article. But a demonstration of the merits or demerits of a particular interpretive -ism is at most a byproduct of the interpretive approach adopted rather than an independent objective.

The particular combination of durability and evanescence, as well as relative strength and weakness, of legal arguments like Charles Hammond's reveals an interesting phenomenon of legal reasoning. Implicit in the claims not only that Hammond was correct, but also that his correctness can be appreciated today is a claim about the ability of legal reasoning of the sort deployed by Hammond and in this Article to yield recognizably sound conclusions despite decades and decades of change. Yet this assumed feature juxtaposes harshly with the evident truth that Hammond's arguments had no apparent practical effect at the time he wrote and disseminated them.

The conclusion to Hammond's Hampden essays includes an expression of hope that "the judges themselves" would be "among the 'few persons' who will take the pains to read what I have written." 192 The essay series ends with an affirmation of the "right of the citizen to expose what he views as an erroneous doctrine" and an assertion of the corresponding duty of judges to attend to critical examinations of their opinions:

I am far removed from personal acquaintance, or personal collision with any of them. My lot in life is too humble, my station too obscure even to come into personal contact with them, or to hope any thing personal from thus publicly questioning their correctness. It is the right of the citizen to expose what he views as an erroneous doctrine, no matter by what public functionary it is advanced. It is the duty of all public men to give attention to every examination of their opinions, \& to derive improvement from it-That the judges of the supreme court will make every proper use of this review, I entertain no doubt. But for this consideration, I might well regard the whole as labor thrown away. ${ }^{193}$

192 See Charles Hammond, No. XI, reprinted in Review of the Opinion, supra note 15 , at 61. 
This is a poignant conclusion in light of the apparent irrelevance of Hammond's arguments about Cohens $v$. Virginia during his lifetime. In the grand sweep of the law, though, Hammond's labors were not wasted. His essays and other constitutional writings preserve a vision of section 25 and of Article III that may have otherwise been permanently buried under the competing constructions erected by Chief Justice Marshall for the Supreme Court in Cohens. It will profit us to attend now and in the future to what Hammond wrote then.

\section{Conclusion}

If this Article's core claim about section 25 is correct, every casebook, treatise, scholarly work, and so on that purports to provide an account of what Congress did in section 25 of the Judiciary Act of 1789 must be changed. In particular, those accounts must come to grips not only with the possibility that the appellate review authorized in section 25 did not encompass state criminal prosecutions but also that section 25 included an amountin-controversy requirement. Put another way, the strong version of the revisionist interpretation of section 25 offered in this Article matters every time that getting it right about section 25 matters. For a foundational statute like the Judiciary Act of 1789, getting section 25 right matters for a number of issues and in a range of ways. And while the weak version of this Article's core claim does not directly address the "correct" interpretation of section 25, it nevertheless opens up a new perspective on the Marshall Court's construction of Article III.

Perhaps most profoundly, even if only diffusely, evaluation of the arguments for civil-only section 25 may induce greater epistemic humility on the part of scholars seeking to understand Article III and the development of federal jurisdiction. From 1789 through 1820, the Supreme Court of the United States decided hundreds of cases, including a few dozen appeals from state courts. All of these state court appeals were in civil suits; none were in criminal prosecutions. If one were asked to provide a full account of Supreme Court appellate review of state criminal prosecutions from the beginning of the Supreme Court's existence all the way through the Chief Justiceships of John Jay and Oliver Ellsworth, and halfway through John Marshall's, only three words would be needed: There was none. It is noteworthy-if one pauses to think about it-that the Supreme Court sat for over three decades before it first engaged in direct appellate review of a state criminal prosecution turning on a question of federal law. Yet lawyers, judges, and scholars have largely ignored the pre-history of Supreme Court review of state criminal prosecutions. Sometimes, it seems, the obvious can blind. 